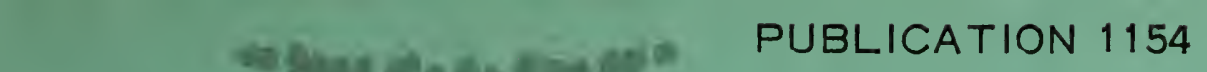

CHEMICAL METHODS FOR ANALYSIS

OF FRUIT AND VEGETABLE PRODUCTS

ada

ire Date

CANADA DEPARTMENT OF AGRICULTURE C. 3 



\title{
CHEMICAL METHODS FOR ANALYSIS OF FRUIT AND VEGETABLE PRODUCTS
}

\author{
Compiled \\ by \\ J. A. Ruck
}

Contribution No. B7, Research Station, Summerland, B.C.

Research Branch

CANADA DEPARTMENT OF AGRICULTURE 
First published as Contribution 350,

Chemistry Division, Science Service, 1956

Revised - November 1963

\section{ACKNOWLEDGMENT}

The author is indebted to the following at the Research Station, Summerland, for help in preparing the manuscript and checking the methods recommended in this publication: A. Woyls, F.E. Atkinson, J. A. Kitson and D. R. MacGregor. 


\section{CONTENTS}

Introduction $\ldots \ldots \ldots \ldots \ldots \ldots \ldots \ldots \ldots \ldots \ldots \ldots \ldots \ldots \ldots$

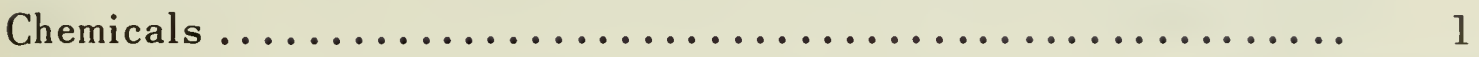

Apparatus and Equipment $\ldots \ldots \ldots \ldots \ldots \ldots \ldots \ldots \ldots \ldots \ldots \ldots$

Calculation of Results $\ldots \ldots \ldots \ldots \ldots \ldots \ldots \ldots \ldots \ldots \ldots \ldots \ldots$

Jams, Jellies and Marmalades ....................... 2

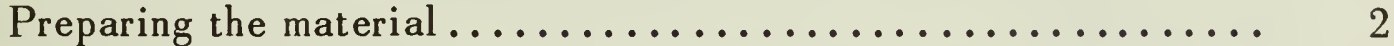

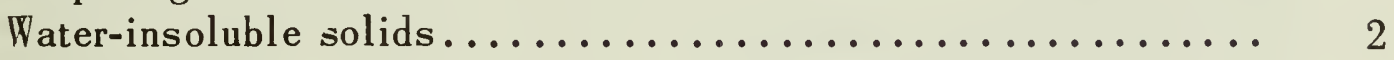

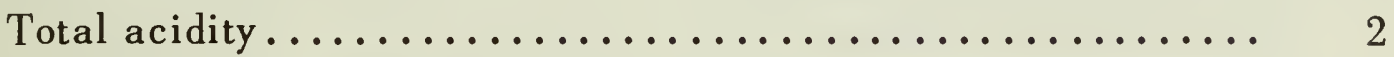

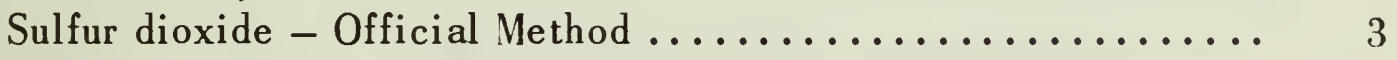

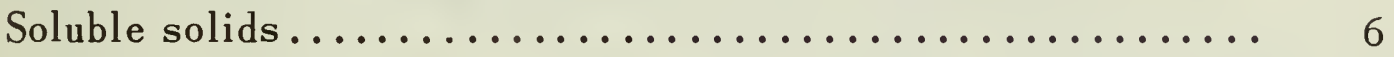

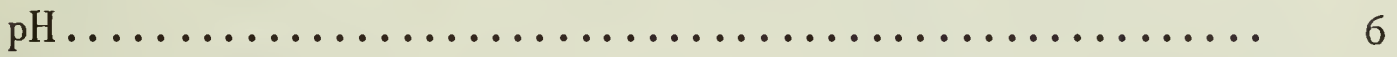

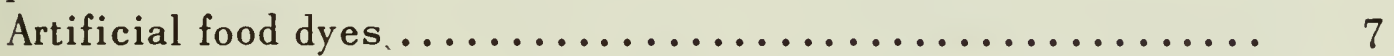

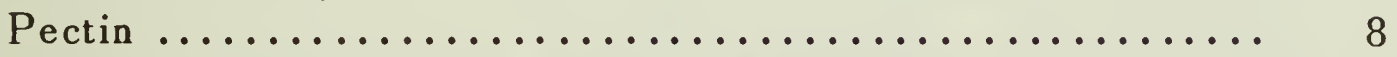

Total and reducing sugars - Lane and Eynon Method ......... 9

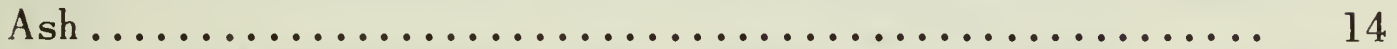

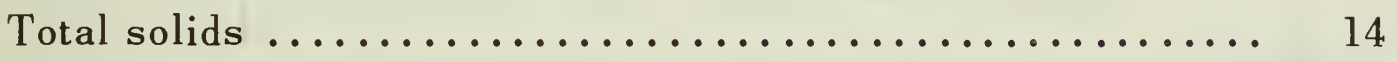

Fruit Juices ............................... 16

Ascorbic acid - Indophenol Method .................. 16

- Colorimetric Method ................. 17

Total and reducing sugars - Lane and Eynon Method ......... 19

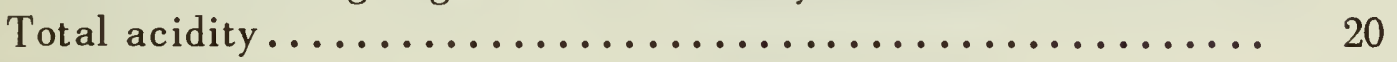

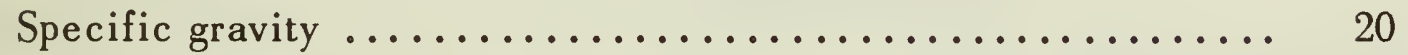

Soluble solids............................ 21

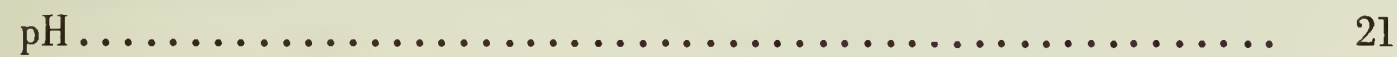

Candied Fruit and Peel ......................... 22

Preparing the material ........................ 22

Total and reducing sugars - Lane and Eynon Method ........ 22

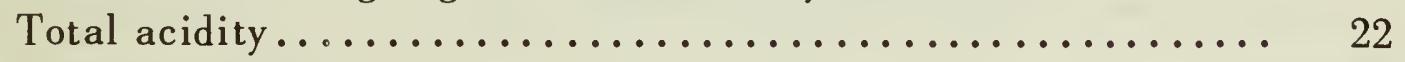

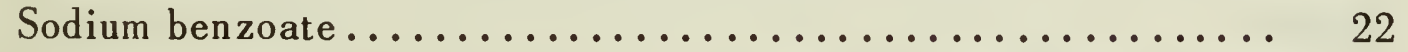

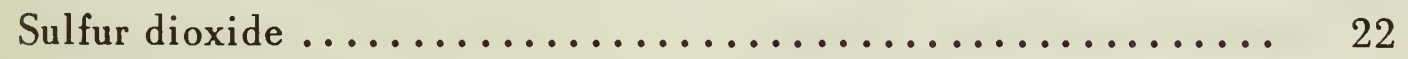

Artificial food dyes ........................... 22

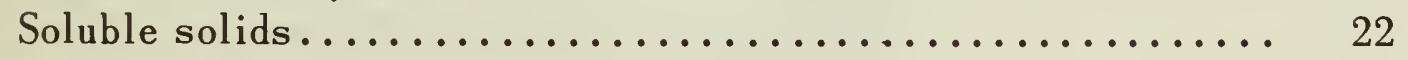

Dehydrated Fruits and Vegetables ..................... 23

Dehydrated apples - Preparing the material ............ 23

- Moisture ..................... 23

- Sulfur dioxide ................. 23

Dehydrated potatoes, carrots, etc. - Moisture ............ 23 
Mincemeat ..................................... 24

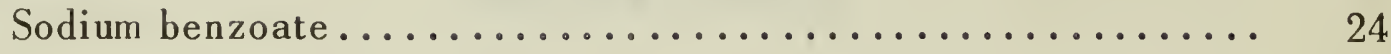

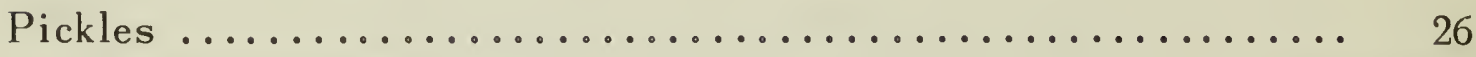

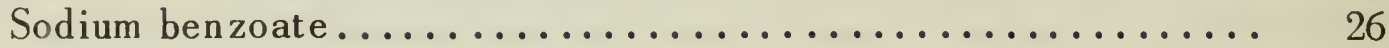

Sodium chloride ........................... 26

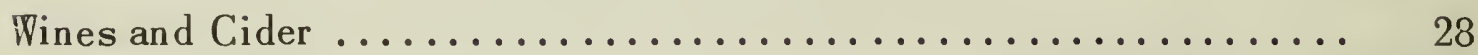

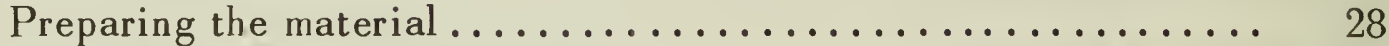

Alcohol - Pycnometer Method ................... 28

- By Distillation and Hydrometer .............. 29

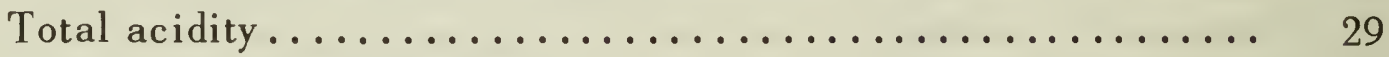

Tannin and coloring matter...................... 30

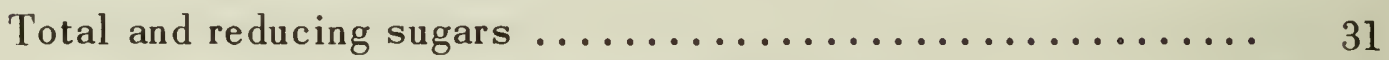

- Total sugar - Dry wines and cider ........... 31

- Sweet wines and cider ................... 32

Iron - Colorimetric Method ...................... 32

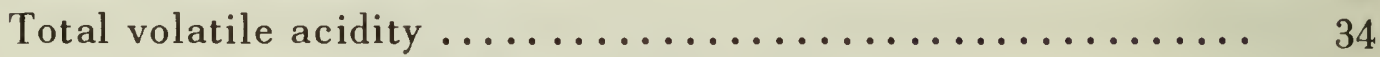

Volatile acidity - Exclusive of $\mathrm{SO}_{2} \ldots \ldots \ldots \ldots \ldots \ldots \ldots \ldots \ldots \ldots \ldots \ldots \ldots \ldots$

Extract - Hydrometer Method ................... 36

- Oven Method....................... 36

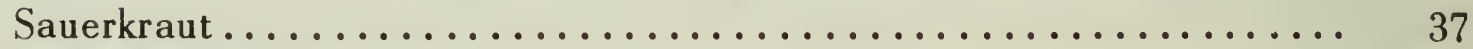

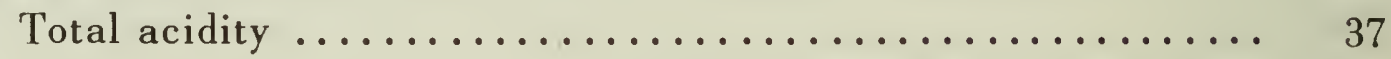

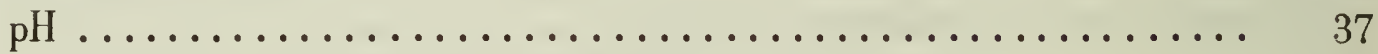

Fruit Preserved in Sulfur Dioxide.................... 37

Sulfur dioxide - Official Method.................. 37

- Control Method ................... 37

Miscellaneous Procedures .......................... 39

Calcium - Official Method.................... 39

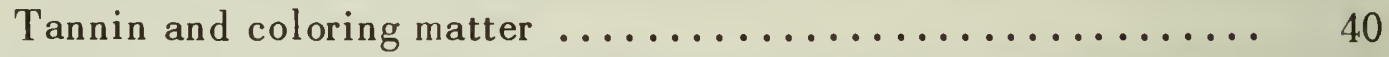

Enzyme tests for adequacy of blanching in frozen vegetables... 41

Crude fat or ether extract..................... 42

Estimation of calorie content of diet foods............. 43

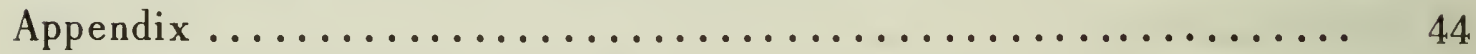

Standard solutions - Acids .................... 44

- Bases....................... 45

- Oxidizing and reducing solutions ....... 45

- Indicators ..................... 46 


\section{INTRODUCTION}

In the Fruit and Vegetable Processing Laboratory, Research Station, Summerland, the work includes research with new products, analyses of commercial fruit products, and the development of procedures for use in establishing grades and standards. In addition, special problems in the fruit and vegetable processing industry are studied.

Chemical methods of analysis are constantly changing through revision, and adoption of improved techniques. The methods described in this publication are those inost commonly used for analyzing the products listed and are in current use at the Summerland laboratory. These methods should be useful for all units and laboratories engaged in fruit and vegetable research.

Since the printing of the first edition of this manual, several new methods have been adopted and the procedures are included in this edition.

After the outline of each procedure is a list of references that constitutes acknowledgment of information used in this publication. 
Digitized by the Internet Archive in 2012 with funding from

Agriculture and Agri-Food Canada - Agriculture et Agroalimentaire Canada 


\section{CHEMICALS}

All chemicals mentioned in the following procedures are of chemically pure (C.P.) grade or equivalent quality. Reagents commonly used, such as mineral acids and ammonia, are not included in the lists of reagents for individual procedures. When they are mentioned in procedures, C.P. concentrated reagents are to be used.

Concentrations of solid reagent solutions are indicated in percentages on a weight/volume basis: a definite weight of solid reagent is dissolved in water and made up to a total volume of $100 \mathrm{ml}$. Concentrations of liquid reagents are indicated in percentages on a volume/volume basis: the given volume of the concentrated reagent is diluted to a total volume of $100 \mathrm{ml}$. with water unless otherwise stated. Reagents are sometimes designated on a ratio basis such as $(4+1)$, which means 4 parts of reagent to 1 part water. Water mentioned in any procedure is distilled water.

Technical grade chemicals usually cost appreciably less than C.P. chemicals and where possible they should be used. In the following procedures these are indicated by the abbreviation (tech.) after the reagent.

\section{APPARATUS AND EQUIPMENT}

Special apparatus and equipment required for the various procedures are given in the description of the analytical method involved. Unless otherwise stated, temperatures mentioned are in degrees Centigrade. When liquid measurements of solutions and reagents are required to be accurate, pipette measurements are specified. Otherwise, a graduated cylinder or similar measure is satisfactory.

\section{CALCULATION OF RESULTS}

The results of analysis of food products are usually expressed on the basis of fresh weight, but occasionally on a moisture-free basis. The values in the following procedures are expressed as percentages by weight or percentages by volume of the original products.

The weights and aliquots suggested in the procedures are usually sufficient where an average amount of the constituent is present. In some cases a more suitable weight or aliquot of the sample may have to be determined by experiment. 


\section{JAMS, JELLIES AND MARMALADES}

\section{PREPARING THE MATERIAL}

Remove $1 / 3$ to $1 / 2$ of the material for analysis from the container and blend for 1 to 2 minutes in a Waring blendor. Take the portion vertically through the container to avoid removing excess berries or seeds that may have floated to the top. Stir the portion well with a spoon before taking each sample for weighing.

\section{WATER-INSOLUBLE SOLIDS}

\section{Principle}

A weighed sample is boiled with water to extract soluble material. The insoluble material is collected on a previously dried, weighed filter paper, and washed with hot water. The insoluble solids are then dried in an oven and weighed.

\section{Procedure}

Weigh to the nearest 0.01 gm., on a torsion balance, duplicate 25-gm. samples of the blended portion. Transfer each duplicate to a 400-ml. beaker with hot water and dilute with additional hot water to about $200 \mathrm{ml}$. Mix and boil gently for 15 to 20 minutes. Transfer one of the duplicate samples to a $250-\mathrm{ml}$. volumetric flask, cool and make up to volume at $20^{\circ}$. (The filtrate from this is used later for determining acidity. Mark filtrate "A.") Filter separately the sample from the volumetric flask and that from the beaker through No. 4 Whatman paper $(15.0 \mathrm{~cm}$.) that waspreviously washed with hot water, oven-dried for 2 hours at $100^{\circ}$, cooled in a desiccator and weighed in a covered weighing dish ( $7-\mathrm{cm}$. diam.). Wash with $800 \mathrm{ml}$. of hot water, loosening the water-insoluble solids from filter paper with each addition. Transfer filter paper to original weighing dish. Dry overnight at 100 to $105^{\circ}$, cool in desiccator and weigh.

\section{Calculations}

$\%$ water-insoluble solids $=$ wt. of dry insoluble material $\times 4$.

\section{TOTAL ACIDITY}

\section{Principle}

Total acidity is determined by titrating an aliquot of the water extract with standard sodium hydroxide to $\mathrm{pH} 8.1$ using a $\mathrm{pH}$ meter. 


\section{Procedure}

Use filtrate A from the previous water-insoluble solids determination. Pipette $50 \mathrm{ml}$. of the filtrate into $250 \mathrm{ml}$. beaker. Add about $100 \mathrm{ml}$. water and titrate with $0.1 \mathrm{~N} \mathrm{NaOH}$ to $\mathrm{pH} 8.1$, using a $\mathrm{pH}$ meter. Record the amount of $\mathrm{NaOH}$ required and calculate total acidity. Total acid is expressed as the percentage of the predominant acid in the fruit. In small fruits such as strawberries, raspberries, black currants, gooseberries and citrus fruits, this is taken as citric acid; in plums, cherries, peaches and apricots, as malic acid; and in grapes, as tartaric acid.

\section{Calculations}

Assume the titration required $5.7 \mathrm{ml} .0 .1 \mathrm{~N} \mathrm{NaOH}$ and the original sample weight was $25 \mathrm{gm}$. The sample was diluted to $250 \mathrm{ml}$. and $50-\mathrm{ml}$. aliquot used for titration:

$$
\begin{aligned}
\% \text { total acid } & =\frac{1}{10} \times \frac{\text { equiv. wt. of acid } \times \text { normality of } \mathrm{NaOH} \times \text { titer }}{\text { wt. of sample }} \\
& =\frac{1}{10} \times \frac{70.0 \times 0.10 \times 5.7}{5} \\
& =0.140 \times 5.7
\end{aligned}
$$

Equivalent wt. of acids:

Citric (monohydrate) $=70.0 \mathrm{gm} . \quad$ Tartaric $=75.0 \mathrm{gm}$.

Malic $\quad=67.0 \mathrm{gm}$. Acetic $=60.0 \mathrm{gm}$.

\section{SULFUR DIOXIDE}

\section{(Official Method)}

\section{Principle}

The sample is acidified and the evolved sulfur dioxide is swept with carbon dioxide or nitrogen into cold hydrogen peroxide, where the sulfurous acid is oxidized to sulfuric acid. The latter is determined by titration with standard sodium hydroxide.

\section{Reagents}

1. Hydrogen peroxide- $3 \%$ solution

Dilute $200 \mathrm{ml}$. $30 \%$ hydrogen peroxide to about $1,400 \mathrm{ml}$. in a 2,000-ml. graduate. Mix by pouring solution back and forth from a 2,000-ml. beaker to the graduate. Take 100-ml. portion of diluted solution (100-ml. graduate) and titrate in a $250-\mathrm{ml}$. beaker on $\mathrm{pH}$ meter with $0.1 \mathrm{~N} \mathrm{NaOH}$ to $\mathrm{pH} 4.1$. Do not return this portion to main solution. Calculate amount of $\mathrm{NaOH}$ required to neutralize the main solution; add this amount, stir, check the pH. 


\section{Standardization of $\mathrm{H}_{2} \mathrm{O}_{2}$ solution}

Pipette $10 \mathrm{ml}$. of the solution into a $100-\mathrm{ml}$. volumetric flask and make up to volume at $20^{\circ}$. Pipette $5 \mathrm{ml}$. of this diluted solution into $500-\mathrm{ml}$. flask, add about $300 \mathrm{ml}$. water and $10 \mathrm{ml} .6 \mathrm{~N} \mathrm{H}_{2} \mathrm{SO}_{4}$ and titrate with $0.1 \mathrm{~N}$ potassium permanganate to first permanent pink color. If an exact $3 \%$ solution is required, calculate as follows:

$$
1 \mathrm{ml} \text {. 0.1N } \mathrm{KMnO}_{4}=0.0017 \text { gm. } \mathrm{H}_{2} \mathrm{O}_{2}
$$

If the titration required $9.1 \mathrm{ml} .0 .105 \mathrm{~N} \mathrm{KMnO}_{4}$ then

$\% \mathrm{H}_{2} \mathrm{O}_{2}=0.017 \times 9.1 \times$ normality of $\mathrm{KMnO}_{4} \times$ dilution

$$
=0.017 \times 9.1 \times 0.105 \times 200
$$

Adjust solution to $3.0 \%$ with water and always store in arefrigerator.

2. Bromophenol blue-0.1\% solution

Dissolve $0.1 \mathrm{gm}$. in $100 \mathrm{ml}$. water.

3. Phenolphthalein indicator $-0.1 \%$ water.

Dissolve $0.1 \mathrm{gm}$. in $50 \mathrm{ml}$. ethyl alcohol and dilute to $100 \mathrm{ml}$. with

4. Sodium carbonate-saturated solution

Dissolve enough sodium carbonate (tech.) to prepare a saturated solution. Add several drops of phenolphthalein. Discard this solution when it becomes decolorized by adsorption of acids in the carbon dioxide.

\section{Apparatus}

The apparatus illustrated in Figure 1 is pyrex throughout. All parts have either $24 / 40$ standard taper or $18 / 9$ spherical joints.

\section{Procedure}

Circulate cold water through condenser. Add from a graduated cylinder $20 \mathrm{ml} .3 \%$ hydrogen peroxide to the Erlenmeyer flask and $5 \mathrm{ml}$. to the trap. Assemble and connect to condenser. Weigh $50 \mathrm{gm}$. of blended portion and rinse into $500-\mathrm{ml}$. flask through gas inlet tube, using $300 \mathrm{ml}$. water. Replace gas inlet tube immediately, making sure all connections are well greased and tight. Remove the gas inlet tube, and slowly add $20 \mathrm{ml}$. conc. HCl. Replace the tube and see if bubbles enter the receiving flasks. If not, check joints for leaks. Adjust $\mathrm{CO}_{2}$ (passed through a gas washing bottle filled with sodium carbonate solution) or nitrogen ( $99.9 \%$ pure) to give a flow of 15 to 20 bubbles per minute through the tube. Connect the 500 -watt heater and turn to the high position. In about 5 minutes, when solution starts to boil, adjust heater to give a slow boil. Dried fruits or vegetables require 1 hour's boiling. Thirty minutes is enough for all other products. After the solution boils for the required time, wash the hydrogen peroxide solution from the trap into the Erlenmeyer flask. Rinse the trap'with water. 


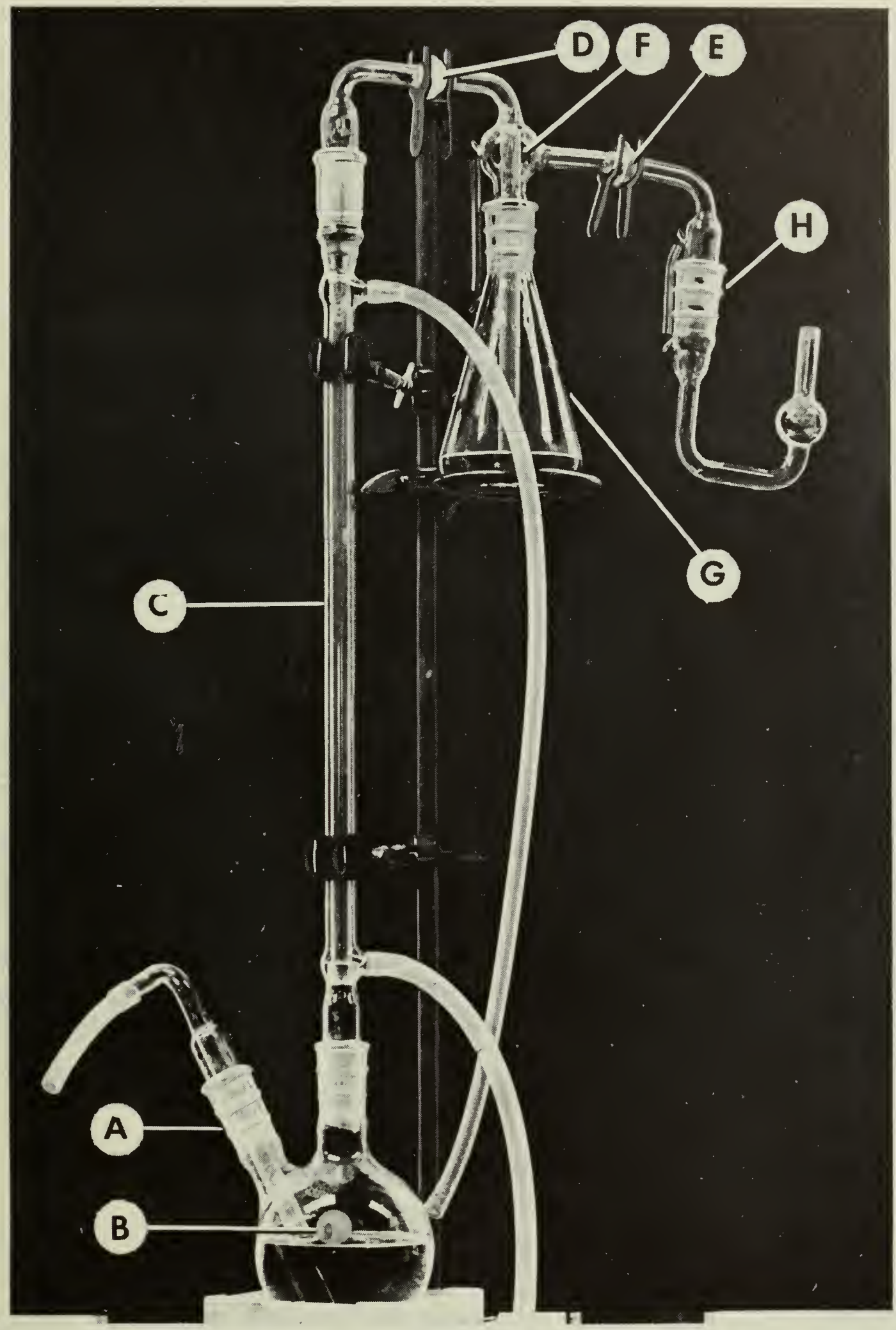

Figure 1.-All-glass apparatus for determining sulfur dioxide. A, Gas inlet tube. B, 500-ml. round-bottom flask。 $C_{*}$ Condenser, $400 \mathrm{~mm}$. jacket length. D-E, 18/9 spherical joints. F, Special adapter. G, 250-ml. Erlenmeyer flask. $H_{0}$ Trap. 
Add 3 drops of bromophenol blue indicator and titrate with $0.05 \mathrm{~N} \mathrm{NaOH}$ solution to pale sky blue end point, using a 5 -ml. microburette (for samples very high in $\mathrm{SO}_{2}$ use a $50-\mathrm{ml}$. burette and $0.1 \mathrm{~N} \cdot \mathrm{NaOH}$ ). Run a blank titration on $20 \mathrm{ml}$. of hydrogen peroxide and correct the results accordingly.

\section{Calculations}

$1 \mathrm{ml} .0 .1 \mathrm{~N} \mathrm{NaOH}=3.2 \mathrm{mg} \cdot \mathrm{SO}_{2}$

If 50-gm. sample required $4.1 \mathrm{ml}$. $0.05 \mathrm{~N} \mathrm{NaOH}$ :

$$
\text { p.p.m. } \begin{aligned}
\mathrm{SO}_{2} & =\frac{32 \times 1000 \times \text { normality of } \mathrm{NaOH} \times \mathrm{ml} \text {. of } \mathrm{NaOH}}{\text { wt. of sample }} \\
& =\frac{32 \times 1000 \times 0.05 \times 4.1}{50}
\end{aligned}
$$

\section{References}

Association of Official Agricultural Chemists. Official methods of analysis.

8th ed. pp. 507-509. Washington, D.C. 1955.

Shipton, J. Estimation of sulfur dioxide in dried foods. Food Preservation Quarterly 14 (3): 54-56. 1954.

\section{SOLUBLE SOLIDS}

\section{Principle}

Soluble solids are determined with a refractometer equipped with a percent sugar scale.

\section{Procedure}

Take representative samples of a well-mixed portion of jam or jelly free from seed and fiber, place on refractometer prisms and read directly at $20^{\circ}$. If temperature correction is necessary, use the correction factor given in Table 1. It is preferable to have the instrument maintained at constant temperature by circulating water through the prisms. For very accurate results a correction should be made for water-insoluble solids as follows:

$$
\begin{aligned}
\% \text { soluble solids }= & \% \text { solids by refractometer } \times \frac{(100-a)}{100} \\
& \text { where } a=\% \text { water-insoluble solids. }
\end{aligned}
$$

\section{$\mathrm{pH}$}

\section{Principle}

The effective acidity is determined by taking a direct reading on a $\mathrm{pH}$ meter.

\section{Procedure}

Standardize the $\mathrm{pH}$ meter with a $\mathrm{pH} 4.0$ buffer solution. 
Place 50 to $75 \mathrm{gm}$. of well-mixed portion in a $100-\mathrm{ml}$. beaker and read on $\mathrm{pH}$ meter. When the first reading is completed, wipe electrodes with. small piece of cotton soaked in distilled water. Rinse electrodes with water from wash bottle, dry with a piece of filter paper and continue with the next determination.

\section{Table 1. - Temperature Corrections for the Standard Model of Sugar Refractometer Calibrated for $20^{\circ} \mathrm{C}^{1}$}

\begin{tabular}{|c|c|c|c|c|c|c|c|c|c|c|c|c|c|c|}
\hline \multirow{3}{*}{$\begin{array}{l}\text { Tempera- } \\
\text { ture }\end{array}$} & \multicolumn{14}{|c|}{ Percentage of dry substance } \\
\hline & 5 & 10 & 15 & 20 & 25 & 30 & 35 & 40 & 45 & 50 & 55 & 60 & 65 & 70 \\
\hline & \multicolumn{14}{|c|}{ Subtract from dry-substance percentages } \\
\hline $15^{\circ} \mathrm{C}$. & .29 & .31 & .33 & .34 & .34 & .35 & .36 & $.37^{\prime}$ & .37 & .38 & .39 & .39 & .40 & 40 \\
\hline 16 & .24 & .25 & .26 & .27 & 28 & .28 & .29 & .30 & & .30 & 1 & 1 & 32 & \\
\hline 17 & 18 & .19 & .20 & .21 & 21 & .21 & .22 & .22 & & .23 & & 23 & 24 & \\
\hline 1 & 13 & & .14 & 14 & & & & & & & & & & \\
\hline & .06 & & .07 & .07 & & & & & & & & & & \\
\hline \multicolumn{15}{|c|}{ Add to dry-substance percentages } \\
\hline 21 & 77 & & .07 & .07 & .0 & .03 & .03 & .08 & .08 & .08 & .08 & .08 & & \\
\hline 2 & 13 & .14 & .14 & .15 & & & & .15 & & .1 & .1 & & & \\
\hline 2 & .20 & .2 & .22 & .22 & & 1.2 & .23 & .23 & & .24 & .2 & .24 & & 0 \\
\hline 2 & .27 & .28 & .29 & .30 & .30 & .31 & .31 & .31 & .31 & .31 & .32 & 2 & .32 & .3 \\
\hline 2 & .35 & .36 & .37 & .38 & .38 & .39 & .40 & .40 & .40 & .40 & .40 & .40 & .40 & .10 \\
\hline 26 & .42 & .43 & .44 & .45 & .46 & .47 & .48 & .48 & .48 & .48 & 臬. & .48 & .43 & .48 \\
\hline 27 & .50 & .52 & .53 & .54 & .55 & .55 & .56 & $\mid .56$ & .56 & .56 & .56 & .56 & .56 & .56 \\
\hline 28 & .57 & .60 & .61 & .63 & .63 & .64 & .64 & .64 & .64 & .64 & .64 & .64 & .64 & .64 \\
\hline 29 & .66 & .68 & .69 & .71 & .7 & .73 & .73 & .73 & .73 & .73 & .73 & .73 & .73 & .73 \\
\hline 30 & .74 & .77 & .78 & .79 & .80 & .80 & .81 & .81 & .81 & .81 & .81 & .81 & .81 & .81 \\
\hline
\end{tabular}

${ }^{1}$ Proceedings of the Ninth Session of the International Commission for Uniform Methods of Sugar Analysis, London. 1936.

\section{ARTIFICIAL FOOD DYES}

(Water-Soluble Coal Tar Dyes)

\section{Principle}

The dye is absorbed by a piece of white woolen cloth from an acidified solution. Individual pieces of the cloth are moistened separately with conc. $\mathrm{HCl}$, conc. $\mathrm{H}_{2} \mathrm{SO}_{4}$, conc. $\mathrm{NH}_{4} \mathrm{OH}$ and $10 \% \mathrm{NaOH}$. The colors developed are compared with those of known dyes.

This method is not conclusive but does provide a useful and quick estimation of the presence of some artificial food dyes, particularly where the dye is present in pure form. 


\section{Procedure}

Dilute 20- to 40-gm. sample with 1 to 3 volumes of water, add 3 or 4 drops of conc. $\mathrm{HCl}$ and a small piece of white woolen cloth (Nun's veiling). Heat to boiling and then cool. Rinse the dyed cloth thoroughly in running water, squeeze out excess water and cut into four small pieces; place each in a separate depression of a white porcelain spot plate. Moisten separate pieces with conc. $\mathrm{HCl}$, conc. $\mathrm{H}_{2} \mathrm{SO}_{4}, 10 \% \mathrm{NaOH}$ and conc. $\mathrm{NH}_{4} \mathrm{OH}$.

The hue of many coloring matters varies markedly upon treatment with acids or alkalies. This variation is also influenced by concentration of reagents and quantity of dye present. An unknown dye color should be compared with that of a known dye at about the same visual density. Table 2 shows color changes produced on wool dyed with 0.1 to $0.5 \%$ solutions of permitted food dyes.

\section{Table 2.-Color Reactions Produced on Dyed Fibers by Various Reagents}

\begin{tabular}{|c|c|c|c|c|}
\hline $\begin{array}{l}\text { Coloring } \\
\text { matter }\end{array}$ & $\begin{array}{l}\text { Hydrochloric } \\
\text { acid }\end{array}$ & $\begin{array}{l}\text { Sulfuric } \\
\text { acid }\end{array}$ & $\begin{array}{l}10 \% \mathrm{NaOH} \\
\text { solution }\end{array}$ & $\begin{array}{l}\text { Ammonium } \\
\text { hydroxide }\end{array}$ \\
\hline Amaranth & Slightly darker & $\begin{array}{l}\text { Violet to } \\
\text { brownish }\end{array}$ & $\begin{array}{l}\text { Dull brownish } \\
\text { to orange-red }\end{array}$ & Little change \\
\hline Erythrosine & Orange-yellow & Orange-yellow & No change & No change \\
\hline Ponceau 3R & Little change & Little change & Dull orange & Little change \\
\hline Ponceau SX & Deeper red & Deeper red & Orange-yellow & Orange-yellow \\
\hline Tartrazine & Slightly darker & Slightly darker & Little change & Little change \\
\hline $\begin{array}{l}\text { Naphthol } \\
\text { yellow S }\end{array}$ & $\begin{array}{l}\text { Almost decolor- } \\
\text { ized }\end{array}$ & $\begin{array}{l}\text { Very pale, dull } \\
\text { brown }\end{array}$ & No change & No change \\
\hline $\begin{array}{l}\text { Light green } \\
\text { SF yellowish }\end{array}$ & $\begin{array}{l}\text { Pale orange- } \\
\text { yellow }\end{array}$ & $\begin{array}{l}\text { Yellowish } \\
\text { brown }\end{array}$ & Decolorized & Decolorized \\
\hline $\begin{array}{l}\text { Brilliant blue } \\
\text { FCF }\end{array}$ & Yellow & Yellow & No change & No change \\
\hline
\end{tabular}

References

Association of Official Agricultural Chemists. Official methods of analysis, 7th ed. p. 658. Washington, D.C. 1950.

\section{PECTIN}

\section{(As Calcium Pectate) $)^{2}$}

\section{Principle}

Pectin is precipitated as calcium pectate from an acid solution by the addition of calcium chloride. The calcium pectate precipitate is washed with water until chloride-free, then dried and weighed.

${ }^{1}$ Modification Carré and Haynes method by Dr. McInney, Food and Drugs Laboratory, Ottawa, 1944. 


\section{Reagents}

1. Acetic acid-normal solution (approximate)

Dilute $30 \mathrm{ml}$. C.P. glacial acetic acid to $500 \mathrm{ml}$. with water.

2. Calcium chloride-normal solution (approximate)

Dissolve $27.5 \mathrm{gm} . \mathrm{CaCl}_{2}$ (anhydrous) in water and dilute to $500 \mathrm{ml}$.

3. Silver nitrate- $1 \%$ solution

Dissolve $1 \mathrm{gm} . \mathrm{AgNO}_{3}$ in water and dilute to $100 \mathrm{ml}$.

\section{Procedure}

Weigh $50 \mathrm{gm}$. of a blended portion into an $800-\mathrm{ml}$. beaker. Add about $400 \mathrm{ml}$. water and boil for $\mathrm{l}$ hour, replacing water lost by evaporation. Transfer contents of beaker to $500-\mathrm{ml}$. volumetric flask and make up to volume at $20^{\circ}$. Shake well and filter through No. 4 Whatman paper into 500-ml. Erlenmeyer flask.

After mixing the sample by rotating the Erlenmeyer flask, pipette duplicate $100-\mathrm{ml}$. aliquots into $800-\mathrm{ml}$. beakers. Add $300 \mathrm{ml}$. water and 10 ml. $1 \mathrm{~N} \mathrm{NaOH}$ from a pipette, stirring constantly, and let stand overnight.

Add $50 \mathrm{ml}$. of $1 \mathrm{~N}$ acetic acid, with stirring, and allow to stand for 5 minutes. Add $25 \mathrm{ml}$. of $1 \mathrm{~N} \mathrm{CaCl}{ }_{2}$ solution, with stirring. Allow to stand for 1 hour. Heat to boiling and boil for 1 minute. Filter through $41 \mathrm{H}$ Whatman paper $(15.0 \mathrm{~cm}$.) that was previously washed with hot water, oven-dried for 2 hours at $100^{\circ}$. cooled in a desiccator and weighed in a covered weighing dish. Wash precipitate with almost boiling water until chloride-free (test with $\mathrm{AgNO}_{3}$ ). Transfer filter paper to original weighing dish. Dry overnight at $100^{\circ}$, cool in desiccator and weigh.

\section{Calculations}

$$
\% \text { Ca pectate }=\frac{\text { wt. of Ca. pectate } \times 100}{\text { wt. of sample }}
$$

\section{References}

Carré, M. H., and D. Haynes. The estimation of pectin as calcium pectate and the application of this method to the determination of the soluble pectin in apples. Biochem. J. 16: 60-69. 1922.

\section{TOTAL AND REDUCING SUGARS}

\section{(Lane and Eynon Method)}

\section{Principle}

Invert sugar reduces the copper in Fehling's solution to red, insoluble cuprous oxide. The volume of the unknown sugar solution required to completely reduce a measured volume of Fehling's solution is determined by titration, using methylene blue as indicator. 


\section{Reagents}

1. Fehling's solution

Prepare by mixing equal volumes of reagents 2 and 3 immediately before use.

2. Copper sulfate solution

Dissolve $69.28 \mathrm{gm}$. $\mathrm{CuSO}_{4} \cdot 5 \mathrm{H}_{2} \mathrm{O}$ in water, dilute to $1,000 \mathrm{ml}$. and if necessary filter through No. 4 Whatman paper.

3. Alkaline tartrate solution

Dissolve $346 \mathrm{gm}$. Rochelle salt (potassium sodium tartrate, $\mathrm{KNaC}_{4} \mathrm{H}_{4} \mathrm{O}_{6} .4 \mathrm{H}_{2} \mathrm{O}$ ) and $100 \mathrm{gm} . \mathrm{NaOH}$ in water and make up to $1,000 \mathrm{ml}$.

4. Methylene blue indicat or

Dissolve $1 \mathrm{gm}$. methylene blue in $100 \mathrm{ml}$. of water.

5. Neutral lead acetate $-45 \%$ solution

Dissolve $225 \mathrm{gm}$. neutral lead acetate, $\mathrm{Pb}\left(\mathrm{C}_{2} \mathrm{H}_{3} \mathrm{O}_{2}\right)_{2} \cdot 3 \mathrm{H}_{2} \mathrm{O}$, in water and dilute to $500 \mathrm{ml}$.

6. Potassium oxalate-22\% solution

Dissolve $110 \mathrm{gm}$. potassium oxalate $\left(\mathrm{K}_{2} \mathrm{C}_{2} \mathrm{O}_{4} \cdot \mathrm{H}_{2} \mathrm{O}\right)$ in water and dilute to $500 \mathrm{ml}$. An excess of lead acetate in the sugar solution will result in an error in the titration. Determine the exact amount of potassium oxalate solution necessary to precipitate the $\mathrm{Pb}^{++}$from $2 \mathrm{ml}$. of the lead acetate solution as follows: Into each of six $50-\mathrm{ml}$. beakers containing $25 \mathrm{ml}$. water, pipette $2-\mathrm{ml}$. aliquots of the lead acetate solution. To the beakers add 1.6, 1.7, 1.8, 1.9, 2.0 and $2.1 \mathrm{ml}$. potassium oxalate solution, respectively. Filter each through a $41 \mathrm{H}$ Whatman paper and collect the filtrates in 50-ml. Erlenmeyer flasks. To each of the filtrates add a few drops of potassium oxalate solution. The correct amount of potassium oxalate required is the smallest amount which, when added to $2 \mathrm{ml}$. of lead acetate solution, gives a negative test for lead in the filtrate, i.e., no precipitate forms.

The equivalent volumes should be marked on the bottles and employed when the solutions are used in sugar determinations.

\section{Preparing the Standard Sugar Solution}

Weigh $9.5000 \mathrm{gm}$. of pure sucrose. Transfer to a $400-\mathrm{ml}$. beaker, add $100 \mathrm{ml}$. water and $5 \mathrm{ml}$. conc. HCl. Let stand 3 days at $20-25^{\circ}$ to allow inversion to take place. Transfer to a $1,000-\mathrm{ml}$. flask and make up to volume at $20^{\circ}$. The $1 \%$ solution thus obtained is stable for several months.

Neutralize the sugar solution for titration as follows:

Pipette $50 \mathrm{ml}$. of the standard invert solution into a $200-\mathrm{ml}$. volumetric flask and add about $100 \mathrm{ml}$. water. Using phenolphthalein as indicator, add $20 \% \mathrm{NaOH}$ until solution turns pink. Acidify with $1 \mathrm{~N} \mathrm{HCl,} \mathrm{adding} \mathrm{it}$ dropwise, until one drop causes the pink color to disappear. Make up to volume with water. Titrate against $10 \mathrm{ml}$. Fehling's solution as described 
under "Standard Method of Titration." The equivalent volume of neutralized sugar solution is 20.37. The titration should be within $\pm 0.05 \mathrm{ml}$., i.e., 20.32 to $20.42 \mathrm{ml}$.

\section{Method of Titration}

With solutions of unknown concentration, the incremental or trial method is first employed. When the correct dilutions are established, subsequent titrations are performed by the standard method.

\section{The Incremental Method of Titration}

Pipette $10 \mathrm{ml}$. of the mixed Fehling's solution (reagents 2 and 3 ) into a $250-\mathrm{ml}$. flask. Add from the burette (Figure 2) $15 \mathrm{ml}$. of the sugar solution or a larger volume if it is known to be insufficient to completely reduce the quantity of Fehling's solution used. Mix and he at to boiling on a hot plate covered with a clean asbestos-filled gauze. (Note: Wrap adhesive tape on neck of flask to make it easier to hold when hot.) Boil for 15 seconds. If the color remains blue, indicating that the Fehling's solution is not completely reduced, make further $3-$ to $5-\mathrm{ml}$. additions of the sugar solution. Boil the solution for a few seconds after each addition until it is judged unsafe (i.e., only the faintest perceptible blue color remains) to add more sugar solution without risk of passing the end point. Add 2 drops of methylene blue solution and complete the titration by adding the sugar solution dropwise until the indicator is completely decolorized. Record the volume of solution required. The accuracy of the Incremental Method is increased by approaching the end point as rapidly as possible and keeping as nearly as possible to a total boiling period of 3 minutes.

\section{Standard Method of Titration}

Pipette $10 \mathrm{ml}$. of mixed Fehling's solution (reagents 2 and 3) into duplicate 250-ml. Erlenmeyer flasks. Fill the 50-ml. burette with the solution to be titrated. Run into the flask almost the whole volume required to reduce the Fehling's solution, so that not less than $0.5 \mathrm{ml}$. or more than $1.0 \mathrm{ml}$. is required later to complete the titration. Mix the contents of the flask. Heat to boiling and boil moderately for 2 minutes, then add 2 drops of the methylene blue solution, taking care not to allow it to touch the side of the flask. Complete the titration within 1 minute by adding 2 to 3 drops of sugar solution at 5- to 10-second intervals, until the indicator is completely decolorized. At the end point the boiling liquid assumes the brick-red color of precipitated cuprous oxide, which it had before the indicator was added.

\section{Procedure}

Place $50 \mathrm{gm}$. of the blended jam in an $800-\mathrm{ml}$. beaker and add $400 \mathrm{ml}$. of water. To prevent inversion of sugars during boiling extraction, neutralize the solution to $\mathrm{pH} 7.5-8$ with $0.1 \mathrm{~N} \mathrm{NaOH}$, using a $\mathrm{pH}$ meter. 

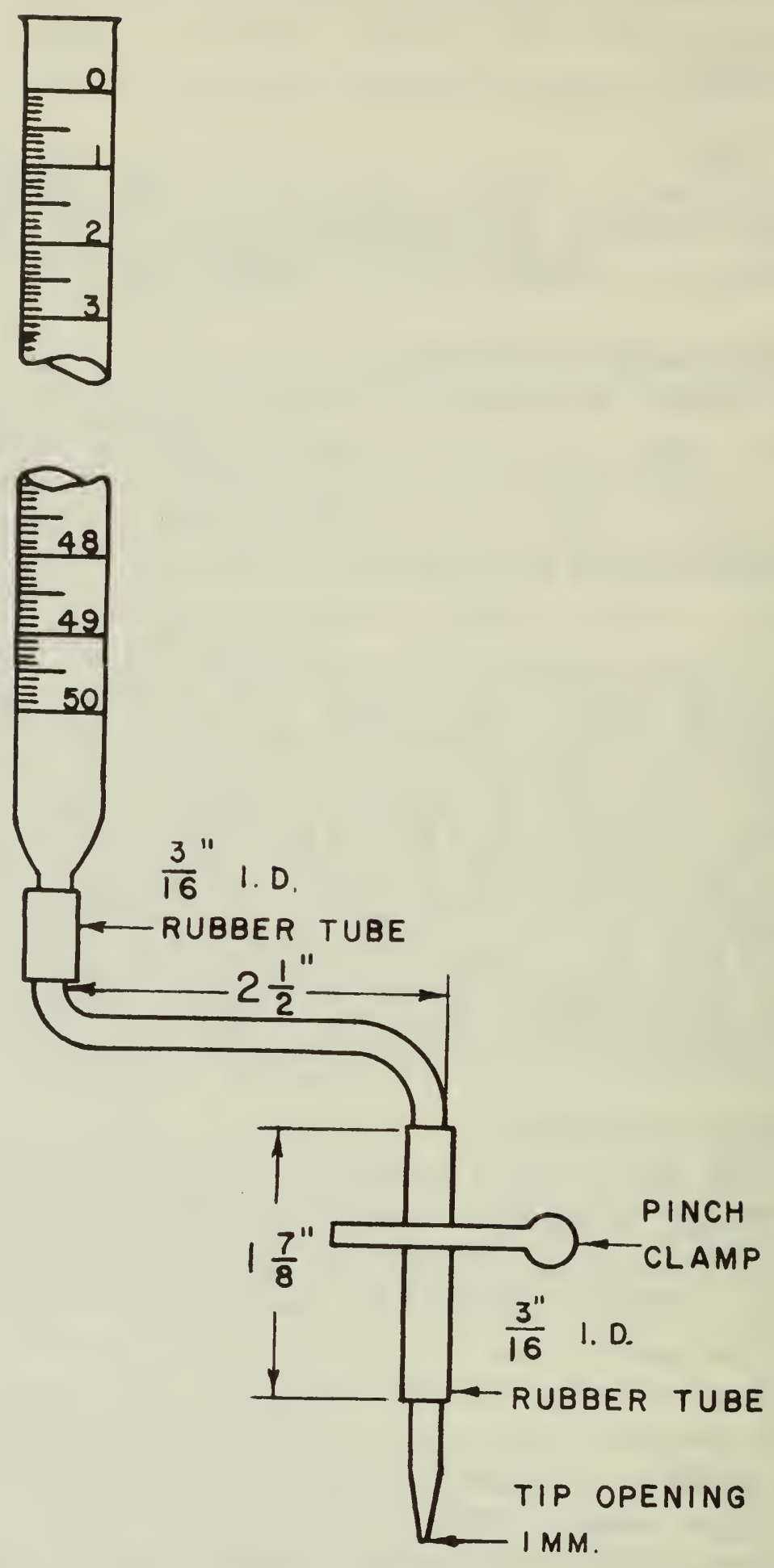

Figure 2。-Burette for sugar titration. 
Boil gently for 1 hour, with occasional stirring. Add boiling water to maintain the original level. Cool, and transfer to a 500-ml. volumetric flask. Make up to volume and filter through No. 4 Whatman paper. Pipette a $100-\mathrm{ml}$. aliquot into a 500-ml. volumetric flask. Add $2 \mathrm{ml}$. of neutral lead acetate solution and about $200 \mathrm{ml}$. of water. Let stand for 10 minutes, then precipitate the excess $\mathrm{Pb}^{++}$with potassium oxalate as follows: add the required amount of potassium oxalate solution as previously determined, make up to volume, shake well and filter through $41 \mathrm{H}$ Whatman paper. Test the filtrate for unprecipitated $\mathrm{Pb}^{++}$with a drop of potassium oxalate. If precipitate forms, add 2 drops of potassium oxalate solution. Refilter and retest for $\mathrm{Pb}^{++}$.

Reducing sugars._Pipette $50 \mathrm{ml}$. of the clarified solution into a 100or 250-ml. volumetric flask. (The dilution depends on the concentration of reducing sugars present.) Make up to volume and titrate by the "Standard Method."

Total sugars.-Pipette $50 \mathrm{ml}$. of the clarified solution into a $250-\mathrm{ml}$. Erlenmeyer flask. Add $5 \mathrm{gm}$. of citric acid and $50 \mathrm{ml}$. of water. Boil gently for 10 minutes to invert sucrose, then cool. Transfer to a $250-\mathrm{ml}$. volumetric flask and neutralize as under "Preparation of Standard Sugar Solution." Make up to volume and titrate by the "Standard Method."

\section{Calculations}

Reducing sugar

$$
\begin{gathered}
\text { \% reducing sugar }=\frac{\text { factor }}{\text { titer }} \times \frac{100}{1000} \times \text { dilution } \\
\text { Using factor from Table } 3
\end{gathered}
$$

If $24.6 \mathrm{ml}$. solution were required for titration:

$$
\begin{aligned}
\% \text { reducing sugar } & =\frac{51.2}{24.6} \times \frac{100}{1000} \times 250 \\
& =\frac{51.2}{24.6} \times 25
\end{aligned}
$$

Total sugar

If $17.8 \mathrm{ml}$. solution were required for titration:

$$
\% \text { total sugar }=\frac{50.7}{17.8} \times 25
$$

\section{References}

Atkinson, F.E., and C.C. Strachan. Candying of fruit in B.C. with special reference to cherries. Fruit Prod. J. 20: 132, 166, 199, 229, 262, 310. 1941. 
Table 3. - Factors for $10 \mathrm{ml}$. of Fehling's Solution to be used with Lane and Eynon Volumetric Method ${ }^{1}$

\begin{tabular}{c|c|c|c}
\hline \hline Titer in ml. & $\begin{array}{c}\text { Invert sugar } \\
\text { no sucrose }\end{array}$ & Titer in ml. & $\begin{array}{c}\text { Invert sugar } \\
\text { no sucrose }\end{array}$ \\
\hline 15 & 50.5 & 33 & 51.7 \\
16 & 50.6 & 34 & 51.7 \\
17 & 50.7 & 35 & 51.8 \\
18 & 50.8 & 36 & 51.8 \\
19 & 50.8 & 37 & 51.9 \\
20 & 50.9 & 38 & 51.9 \\
21 & 51.0 & 39 & 52.0 \\
22 & 51.0 & 40 & 52.0 \\
23 & 51.1 & 41 & 52.1 \\
24 & 51.2 & 42 & 52.1 \\
25 & 51.2 & 43 & 52.2 \\
26 & 51.3 & 44 & 52.2 \\
27 & 51.4 & 45 & 52.3 \\
28 & 51.4 & 46 & 52.3 \\
29 & 51.5 & 47 & 52.4 \\
30 & 51.5 & 48 & 52.4 \\
31 & 51.6 & 49 & 52.5 \\
32 & 51.6 & 50 & 52.5 \\
\hline
\end{tabular}

${ }^{1}$ Association of Official Agricultural Chemists, Official methods of analysis. 8th ed. p. 906, Washington, D.C. 1955.

Principle

\section{ASH}

The dried sample is ignited at $525^{\circ}$ to a white ash.

\section{Procedure}

Weigh duplicate 5- to 10-gm. blended samples into 100-ml. flat-bottom platinum or porcelain dishes. Heat on water bath or oven at $90^{\circ}$ until water is expelled. Place slowly in muffle furnace at $525^{\circ}$ and leave until white ash is obtained. Cool in desiccator and weigh. If black specks appear when water is added to the ash, the sample must be redried and placed in the furnace until a completely white ash is obtained. The time required varies with different products and must be determined by experiment.

\section{Principle}

\section{TOTAL SOLIDS}

A weighed portion of material is dried in a vacuum oven at a temperature not exceeding $70^{\circ}$. Drying time is determined by experiment and is considered sufficient when weighings made at 2 -hour intervals do not differ by more than $3 \mathrm{mg}$. 


\section{Procedure}

Weigh accurately into large $(7 \mathrm{~cm}$.) flat-bottom dishes duplicate 20-gm. blended samples, or a quantity that will give not more than 3 to $4 \mathrm{gm}$. of dry material. If necessary, to get a thin layer of the material, add a few ml. of water and mix thoroughly. Evaporate to dryness on a water bath and dry at $70^{\circ}$ in a vacuum oven at 26 inches or higher vacuum until consecutive weighings made at intervals of 2 hours do not vary more than $3 \mathrm{mg}$. Overnight drying is usually sufficient for most samples.

\section{Calculations}

$$
\% \text { total solids }=\frac{\text { dry wt. }}{\text { wt. of sample }} \times 100
$$




\section{FRUIT JUICES}

\section{ASCORBIC ACID}

(Indophenol Method)

\section{Principle}

Aliquots in oxalic acid solution are titrated with standardized sodium 2:6-dichlorophenolindophenol dye to a faint pink color that persists for 5 to 10 seconds. This method is limited to juices of light color because red pigments obscure the end point.

\section{Reagents}

1. Indophenol dye-0.04\%

Weigh $0.2 \mathrm{gm}$. sodium 2:6-dichlorophenolindophenol. Dissolve in about $200 \mathrm{ml}$. water, if necessary filter through No. 4 Whatman paper into $500-\mathrm{ml}$. volumetric flask and make up to volume at $20^{\circ}$. Store in refrigerator.

2. Oxalic acid-0.4\%

Dissolve $4 \mathrm{gm}$. oxalic acid in water and dilute to $1,000 \mathrm{ml}$.

Standardization of dye.-Dissolve 2 to $3 \mathrm{gm}$. potassium iodide in about $5 \mathrm{ml}$. water in $50-\mathrm{ml}$. Erlenmeyer flask (triplicate). Add $15 \mathrm{ml}$. dye with a pipette and then $10 \mathrm{ml}$. IN HCl. Mix and let stand for 2 minutes. Titrate with freshly prepared $0.01 \mathrm{~N}$ sodium thiosulfate from a microburette $(20 \mathrm{ml}$. $0.1 \mathrm{~N}$ in $200-\mathrm{ml}$. volumetric flask at $20^{\circ}$ ), using 1 to $2 \mathrm{ml}$. starch, until there is no change in color when one drop or less is added. Complete the titration in 1 minute. The dye should be standardized every 48 hours and kept not more than two weeks. Store the dye solution in a refrigerator.

\section{Calculations}

If $15 \mathrm{ml}$. dye required $3.21 \mathrm{ml}$. sodium thiosulfate:

$$
\begin{aligned}
\text { I ml. dye } & =\frac{1}{1000} \times \frac{\mathrm{ml} . \mathrm{Na}_{2} \mathrm{~S}_{2} \mathrm{O}_{3} \times \text { normality of } \mathrm{Na}_{2} \mathrm{~S}_{2} \mathrm{O}_{3} \times 88 \times 1000}{\text { ml. dye }} \\
& =\frac{1}{1000} \times \frac{3.21 \times 0.01 \times 88 \times 1000}{15} \\
& =0.188 \mathrm{mg} \text {. ascorbic acid }
\end{aligned}
$$

\section{Procedure}

Shake can well, determine vacuum using a gauge. Pipette $10 \mathrm{ml}$. juice (25 ml. for juices low in vitamin C) into 100-ml. volumetric flask, make up to volume with $0.4 \%$ oxalic acid and filter through No. 4 Whatman filter paper (clarified juices need not be filtered). Pipette a 5- or 10-ml. aliquot for titration, depending on amount of ascorbic acid present. Add about 15 ml. oxal ic acid (0.4\%) and titrate in a 50-ml. Erlenmeyer flask with $0.04 \%$ 
dye to a faint pink end point lasting for 5 to 10 seconds. Titration must be completed within 1 minute and the total dye required should not exceed 1.5 $\mathrm{ml}$. A microburette should be used for the dye.

\section{Calculations}

mg. ascorbic acid per $100 \mathrm{ml}$. juice $=$ dye equivalent $\times$ titer $\times$ dilution. If $1.05 \mathrm{ml}$. dye were required for titration:

$\mathrm{mg}$. ascorbic acid per $100 \mathrm{ml}$. juice $=0.188 \times 1.05 \times 200$

$$
=39.4
$$

\section{Rapid Method for Tomatoes}

Blend about $500 \mathrm{gm}$. of tomatoes in a blendor for not more than 5-7 seconds. Weigh a 50 -gm. sample and using $0.4 \%$ oxalic acid transfer to a 250 -ml. volumetric flask. Make up to volume with $0.4 \%$ oxalic acid and filter through No. 4 Whatman paper. Using a 5- or 10-ml. aliquot of filtrate, titrate as above with indophenol dye.

\section{References}

Bessey, O.A., and C. G. King. The distribution of vitamin C in plant and animal tissues, and its determination. J. Biol. Chem. 103: 687-698. 1933.

Strachan, C. C. Factors influencing ascorbic acid retention in apple juice. Canada Dept. Agr. Pub. 732. Tech. Bull. 40. 1942.

\section{ASCORBIC ACID}

\section{(Colorimetric Method)}

\section{Principle}

Ascorbic acid is extracted from the material in a Waring blendor using oxalic acid. The decolorizing effect of the extracted ascorbic acid on indophenol dye is measured with a photoelectric colorimeter.

\section{Apparatus}

1. Photoelectric colorimeter

2. Matched tubes

With a Klett-Summerson, use filter No. 540 .

If matched tubes are not available, mark 4 tubes as follows:

DW - distilled water

S - standard (also used later for unknown solution)

No. 1

No. 2

Use these tubes in the required sequence throughout the procedure. 


\section{Reagents}

1. Stock ascorbic acid solution $-0.1 \%$

Dry ascorbic acid crystals over sulfuric acid. Dissolve $0.2 \mathrm{gm}$. in $0.4 \%$ oxalic acid and dilute to $200 \mathrm{ml}$. with $0.4 \%$ oxalic acid.

2. Working standards (W.S.)

Take $5,10,15,20$ and $25 \mathrm{ml}$. of stock ascorbic acid solution and make each up to $500 \mathrm{ml}$. with $0.4 \%$ oxalic acid. Resulting solutions numbered 1 to 5 contain $1,2,3,4$ and $5 \mathrm{mg}$. ascorbic acid per $100 \mathrm{ml}$. respectively. Check each solution against standard iodine or $0.04 \%$ indophenol dye (use $50 \mathrm{ml}$. W.S. with $0.01 \mathrm{~N}$ iodine and $20 \mathrm{ml}$. W.S. with dye).

3. Dye-sodium 2:6-di chlorophenolindophenol

Dilute $30 \mathrm{ml}$. $0.04 \%$ dye to $1,000 \mathrm{ml}$. (12.0 mg./liter) $(0.0012 \%)$.

\section{Standardization}

To the four matched tubes add reagents as follows:

DW - $10 \mathrm{ml}$. distilled water

S - 1 ml. W.S. No. $1+9$ ml. water. Mix.

No. 1 - $1 \mathrm{ml} .0 .4 \%$ oxalic acid

No. 2 - 1 ml. W.S. No. 1

Adjust galvanometer to zero with tube DW in instrument. To tube No. 1 , add $9 \mathrm{ml}$. dye, invert to mix, insert into instrument in place of DW and take galvanometer reading in 15 seconds. Record as $\mathrm{L}_{1}$.

Adjust galvanometer to zero with tube $\mathrm{S}$ in instrument. To tube No. 2 add $9 \mathrm{ml}$. dye, invert to mix, insert into instrument in place of tube $\mathrm{S}$ and take galvanometer reading in 15 seconds. Record as $\mathrm{L}_{2}$.

In succession, record $L_{1}$ and $L_{2}$ readings for each working standard, rinsing the tubes with distilled water and drying between each determination.

On graph paper, against concentration of ascorbic acid in mg. per 100 ml. as abscissa, plot readings $L_{1}-L_{2}$ for each working standard. Draw standard curve.

\section{Preparing the Sample}

Weigh 350 gm. $0.4 \%$ oxalic acid into blendor jar. Add exactly $50 \mathrm{gm}$. of representative portion of solid material. Blend for 3 minutes and filter through No. 4 Whatman paper. If material is juice, pipette $50 \mathrm{ml}$. into 250 -ml. volumetric flask and make up to volume, using $0.4 \%$ oxalic acid. Filter if necessary and mark as filtrate.

\section{Procedure}

Obtain reading $L_{1}$ as described under "Standardi zation."

To tube $\mathrm{S}$ add $1 \mathrm{ml}$. filtrate $+9 \mathrm{ml}$. water, mix and adjust galvanometer to zero. 
To tube No. 2 add $1 \mathrm{ml}$. filtrate $+9 \mathrm{ml}$. dye, invert to mix, insert into instrument in place of tube $\mathrm{S}$ and take reading in 15 seconds. Record as $\mathrm{L}_{2}$.

From the standard curve find the concentration of ascorbic acid in mg. per $100 \mathrm{ml}$. filtrate corresponding to $\mathrm{L}_{1}-\mathrm{L}_{2}$.

\section{Calculations}

mg. ascorbic acid per 100 gm. = ascorbic acid in mg. per $100 \mathrm{ml}$. filtrate $\times$ dilution.

Note: Unknown must contain 0.01 to $0.05 \mathrm{mg}$. ascorbic acid per ml.

\section{References}

Bessey, O.A. A method for the determination of small quantities of ascorbic acidand dehydroascorbic in turbid and colored solutions in the presence of other reducing substances. J. Biol. Chem. 126: 771-784. 1938.

Evelyn, K. A., H. T. Mallory and C. Rosen. The determination of ascorbic acid in urine with the photoelectric colorimeter. J. Biol. Chem. 126: 645-654. 1938.

Loeffler, H.J., and J. D. Ponting. Ascorbic acid. Rapid determination in fresh, frozen or dehydrated fruits and vegetables. Ind. Fng. Chem. Anal. ed. 14: 846-849. 1942.

\section{TOTAL AND REDUCING SUGARS}

(Lane and Eynon Method)

Reagents-See "Jams, Jellies and Marmalades."

\section{Procedure}

Weigh $25 \mathrm{gm}$. filtered (Whatman No. 4) sample and transfer to 400-ml. beaker. Add about $100 \mathrm{ml}$. water, neutralize to $\mathrm{pH} 7.5-8$ with $1 \mathrm{~N} \mathrm{NaOH}$ and transfer into 250-ml. volumetric flask. Add 100-200 ml. water and $2 \mathrm{ml}$. lead acetate solution. Shake and let stand for 10 minutes. Add the necessary amount of potassium oxalate, bring up to volume with water and filter through $41 \mathrm{H}$ or No. 5 Whatman paper. Test filtrate with small amount of potassium oxalate to determine if lead is absent. Mark filtrate "A."

\section{Total sugar}

Pipette $50 \mathrm{ml}$. filtrate A into a 250-ml. Erlenmeyer flask. Add $5 \mathrm{gm}$. citric acid and $50 \mathrm{ml}$. water. Boil gently for 10 minutes to invert the sucrose, then cool. Transfer to a $250-\mathrm{ml}$. volumetric flask or a $250-\mathrm{ml}$. beaker and neutralize, using phenolphthalein as indicator. Add $20 \% \mathrm{NaOH}$ until solution turns pink. Add $1 \mathrm{~N} \mathrm{HCl} \mathrm{dropwise} \mathrm{until} \mathrm{the} \mathrm{pink} \mathrm{color} \mathrm{disappears.} \mathrm{If}$ red color obscures the end point, adjust on $\mathrm{pH}$ meter to 8.1. Make up to volume in a $250-\mathrm{ml}$. flask and titrate by the "Standard Method" under "Jams, Jellies and Marmalades." 
Calculations

$$
\begin{aligned}
\% \text { total sugar } & =\frac{\text { factor }}{\text { titer }} \times \text { dilution } \times \frac{100}{1000} \\
& =\frac{\text { factor }}{\text { titer }}(\text { from Table } 3) \times 5.0
\end{aligned}
$$

\section{Reducing sugar}

For most juices, reducing sugars are low and therefore filtrate A can be used directly in the "Standard Method" of titration as directed under "Jams, Jellies and Marmalades."

\section{Calculations}

$$
\begin{aligned}
\% \text { reducing sugar } & =\frac{\text { factor }}{\text { titer }} \times \text { dilution } \times \frac{100}{1000} \\
& =\frac{\text { factor }}{\text { titer }}(\text { from Table } 3) \times 1.0
\end{aligned}
$$

\section{TOTAL ACIDITY}

\section{Principle}

The total acidity is determined by titrating a diluted sample of juice with standard $\mathrm{NaOH}$ to $\mathrm{pH} 8.1$ using a $\mathrm{pH}$ meter.

\section{Procedure}

If juice has not been clarified previously, filter through No. 4 Whatman paper. Pipette $10 \mathrm{ml}$. of juice into 250 -ml. beaker. Add about $100 \mathrm{ml}$. water and titrate with $0.1 \mathrm{~N} \mathrm{NaOH}$ to $\mathrm{pH} 8.1$, using a $\mathrm{pH}$ meter.

\section{Calculation}

Calculate percent total acidity as the predominant acid present as outlined under acidity of "Jams, Jellies and Marmalades."

\section{SPECIFIC GRAVITY}

\section{Principle}

Specific gravity is determined on a sample of juice, using a hydrometer at the temperature specified.

\section{Procedure}

Cool about $200 \mathrm{ml}$. juice in $250-\mathrm{ml}$. Erlenmeyer flask to exact temperature specific for the hydrometer. Rinse hydrometer graduate with about $50 \mathrm{ml}$. of cooled juice. Fill graduate with juice, insert the hydrometer and take reading. Read the hydrometer at the liquid surface level, not at the top of meniscus. Make sure hydrometer is floating freely when read. 


\section{SOLUBLE SOLIDS}

\section{Procedure}

Take soluble solids reading at $20^{\circ}$, using a refractometer. For apple juice, the percent soluble solids multiplied by 4 should be about equal to the last two figures of the specific gravity reading.

Example: Soluble solids $=12.0 \%$

Specific gravity should be close to 1.048

\section{$\mathrm{pH}$}

\section{Principle}

The $\mathrm{pH}$ as measured directly with a $\mathrm{pH}$ meter indicates the effective acidity of the juice.

\section{Procedure}

Standardize the $\mathrm{pH}$ meter with $\mathrm{pH} 4.0$ buffer.

Pour juice in $50-\mathrm{ml}$. beaker and determine $\mathrm{pH}$. This sample can be used for evaluating flavor, color, aroma and clarity. 


\section{CANDIED FRUIT AND PEEL}

\section{PREPARING THE MATERIAL}

Pass material for analysis through a food chopper and mix thoroughly with a spoon. Products with a liquid portion can be blended. Place in an airtight container and store until ready for analysis.

\section{TOTAL AND REDUCING SUGARS}

(Lane and Eynon Method)

\section{Procedure}

Proceed as under "Total and Reducing Sugars" in "Jams, Jellies and Marmalades."

\section{TOTAL ACIDITY}

\section{Procedure}

Using a 50-gm. sample, proceed as under "Jams, Jellies and Marmalades." Calculate acidity as citric acid.

\section{SODIUM BENZOATE}

\section{Procedure}

Proceed as under "Mincemeat."

\section{SULFUR DIOXIDE}

\section{Procedure} lades."

Using a 50-gm. sample, proceed as under "Jams, Jellies and Marma-

\section{ARTIFICIAL FOOD DYES}

\section{Procedure}

Proceed as under "Jams, Jellies and Marmalades."

\section{SOLUBLE SOLIDS}

\section{Procedure}

If the product has free syrup, use a portion of the syrup and take a soluble solids reading with a refractometer. Temperature correction (Table 1) should be applied if the instrument is not at $20^{\circ}$. 


\section{DEHYDRATED FRUITS AND VEGETABLES}

\section{Dehydrated Apples \\ PREPARING THE MATERIAL}

Pass the material for analysis through a food chopper and mix thoroughly, completing operation as quickly as possible to avoid absorption of moisture or loss of sulfur dioxide. Replace material in airtight container and hold until ready for analysis.

\section{Procedure}

\section{MOISTURE}

Spread about $10 \mathrm{gm}$. of prepared sample over the bottom of a weighed aluminum dish provided with a tightly fitted cover $(7-\mathrm{cm}$. diam.). Begin weighing with the cover off while adding the sample, until slightly over $10 \mathrm{gm}$. Close the dish and weigh accurately and as rapidly as possible.

Dry for 6 hours at $70^{\circ}$ and $26-28$ inches vacuum. Remove the dish cover during this operation. During the drying, admit to oven a slow current of air ( 2 bubbles per second) dried by passing through sulfuric acid. Replace the cover, cool dish in desiccator and weigh.

\section{Calculations}

$$
\% \text { moisture }=\frac{\text { loss in wt. }}{\text { wt. of sample }} \times 100
$$

\section{Procedure}

\section{SULFUR DIOXIDE}

Using a 25-gm. sample, proceed as outlined for "Jams, Jellies and Marmalades." Boiling time is 1 hour.

\section{Preparing the Material}

\section{Dehydrated Potatoes, Carrots, Etc.}

\section{MOISTURE}

Comminute material for analysis in Waring blendor for 1 to 2 minutes. Avoid overheating it. Pass through No. 60 mesh sieve and place in an airtight container.

\section{Procedure}

Weigh duplicate 2- to 3-gm. samples into previously dried and weighed aluminum dishes $(7-\mathrm{cm}$. diam.). Place in vacuum oven and dry under the same conditions as outlined for "Dehydrated Apples."

\section{Calculations}

$$
\% \text { moisture }=\frac{\text { loss in wt. }}{\text { wt. of sample }} \times 100
$$




\section{MINCEMEAT}

\section{SODIUM BENZOATE}

\section{Principle}

In a sodium chloride solution containing an excess of $\mathrm{Na}^{+}$, by addition of sodium hydroxide, benzoic acid is converted into water-soluble sodium benzoate. When the sodium benzoate solution is acidified with excess hydrochloric acid, water-insoluble benzoic acid is formed. The benzoic acid is extracted with chloroform. The chloroform is removed by evaporation and the residue containing benzoic acid is dissolved in alcohol and then titrated with standard sodium hydroxide.

\section{Preparing the Material}

Prepare dry materials such as candied fruit by passing them through a food chopper; pickles, mincemeat, etc., can be blended. Place materials in airtight containers and keep for analysis.

\section{Procedure}

Weigh a 100-gm. sample and transfer to 500-ml. volumetric flask with water (use a powder funnel). Add $10 \mathrm{ml}$. $\mathrm{NaOH}(10 \%)$ and enough sodium chloride to saturate the solution (30 gm. $\mathrm{NaCl}$ for every $100 \mathrm{ml}$. solution). Adjust volume of liquid to about $400 \mathrm{ml}$. and allow to stand 2 hours, with frequent shaking.

Make up to volume with water and filter through No. 4 Whatman paper into a $600-\mathrm{ml}$. beaker. Pipette $100 \mathrm{ml}$. filtered extract into $500-\mathrm{ml}$. shaking bottles and neutralize with $\mathrm{HCl}(1+3)$. If $10 \mathrm{ml}$. $\mathrm{NaOH}$ was added previously, the amount of $\mathrm{HCl}$ required is $2 \mathrm{ml}$. Add $5 \mathrm{ml}$. excess or a total of $7 \mathrm{ml}$. $\mathrm{HCl}(1+3)$. Add $50 \mathrm{ml}$. chloroform to each bottle, close cap and shake gently, releasing the cap periodically to release any pressure. Shake and let stand alternately for 30 minutes. Shaking should be sufficient for proper mixing but not violent enough to cause an emulsion. This point varies with the product.

After 30 minutes, transfer solution slowly to a 500-ml. separatory funnel. When layers have separated, draw off $25 \mathrm{ml}$. of the lower layer and transfer to a 250-ml. beaker. Allow to stand at room temperature until chloroform has evaporated. Dissolve residue by adding $50 \mathrm{ml}$. alcohol $(4+1)$. Add $50 \mathrm{ml}$. water and titrate on a $\mathrm{pH}$ meter to $\mathrm{pH} 8.1$, using $0.05 \mathrm{~N}$ sodium hydroxide from a 5-ml. microburette. Run a blank titration on a solution of alcohol $(4+1)$ and adjust results accordingly.

\section{Calculations}

$1 \mathrm{ml} .0 .05 \mathrm{~N} \mathrm{NaOH}=0.0072$ gm. anhydrous sodium benzoate 
If $1.2 \mathrm{ml} . \mathrm{NaOH}$ were required for titration:

$$
\begin{aligned}
\text { p.p.m. } & =\frac{\text { titer } \times \text { normality } \times 0.0072 \times \text { dilution fact or } \times 1,000,000}{0.05 \times \text { sample wt. }} \\
& =\frac{1.2 \times 0.05 \times 0.0072 \times 10 \times 1,000,000}{0.05 \times 100} \\
& =1.2 \times 0.05 \times 14,400
\end{aligned}
$$




\section{PICKLES}

\section{SODIUM BENZOATE}

\section{Procedure}

See section under "Mincemeat."

\section{SODIUM CHLORIDE}

(Chromate Indicator Method)

\section{Principle}

An aliquot taken from a neutralized solution containing sodium chloride is titrated with a standardized solution of silver nitrate using potassium chromate as an indicator.

\section{Reagents}

1. Silver nitrate- $0.1 \mathrm{~N}$

Dissolve $4.3 \mathrm{gm}$. reagent-grade silver nitrate in water and dilute to $250 \mathrm{ml}$. in a volumetric flask. Standardize against a solution containing $0.50 \mathrm{gm}$. sodium chloride (dried at $110^{\circ}$ before weighing) per $100 \mathrm{ml}$. water.

2. Potassium chromate $100 \mathrm{ml}$.

Dissolve $5 \mathrm{gm}$. potassium chromate in water and dilute to

\section{Procedure}

Take either a 20 -gm. or 20-ml. sample. Add about $100 \mathrm{ml}$. water and neutralize to $\mathrm{pH} 5$ to 7 with dilute sodium hydroxide. If a $\mathrm{pH}$ meter is not available, add methyl orange and enough alkali to change indicator from orange to yellow. Transfer the solution to $200-\mathrm{ml}$. volumetric flask, make up to volume, mix and filter through No. 4 Whatman paper. Pipette 50-ml. aliquot of filtrate into $150-\mathrm{ml}$. Erlenmeyer flask, add $1 \mathrm{ml}$. of potassium chromate solution and titrate with standard silver nitrate solution. The end point is the first permanent red color.

Good lighting should be provided for the titration since the end point is extremely hard to detect with poor illumination. The analyst should satisfy himself that he is able to reproduce his results with a satisfactorily high degree of precision, since certain individuals are color blind to the particular color changes involved. 


\section{Calculations}

$$
\begin{aligned}
\% \mathrm{NaCl} & =\frac{\text { ml. } \mathrm{AgNO}_{3} \times \mathrm{N} \mathrm{AgNO}_{3} \times \text { equiv. wt. of } \mathrm{NaCl} \times 100}{1000 \times \text { wt. of sample }} \\
& =\frac{\mathrm{ml} . \mathrm{AgNO}_{3} \times \mathrm{N} \mathrm{AgNO}_{3} \times 58.45 \times 100}{1000 \times 5(\text { where dilution is } 4)}
\end{aligned}
$$

If the sample is taken by volume rather than by weight, report as percent $w / v$.

\section{References}

National Canners Association. Laboratory manual for the canning industry. Section 21, p. 13. National Canners Association, Washington, D. C. 1954. 


\section{WINES AND CIDER}

\section{PREPARING THE MATERIAL}

Before taking a sample of carbonated drinks for subsequent procedures it is good practice to pour the sample from one beaker to another numerous times. This helps to expel $\mathrm{CO}_{2}$ and removes excess bubbles. If an abnormal amount of acetic acid is present, neutralize with $1 \mathrm{~N} \mathrm{NaOH}$.

\section{ALCOHOL}

\section{(Pycnometer Method)}

\section{Apparatus}

1. Constant-temperature water bath.

2. Pycnometers, $50 \mathrm{ml}$. and $100 \mathrm{ml}$.

3. Distillation apparatus with $500-\mathrm{ml}$. flask and $40-\mathrm{cm}$. condenser.

\section{Calibration}

Clean pycnometer and fill with distilled water. Place in water bath at temperature marked on pycnometer (usually $60^{\circ} \mathrm{F}$.) and leave for 15 minutes. Adjust water level in flask until bottom of meniscus is exactly on graduation mark. With a piece of filter paper dry inside neck of pycnometer. Place back into bath for 10 minutes. Remove flask from water bath, dry, let stand for 10 minutes at room temperature and weigh. Empty pycnometer, rinse with acetone and dry with air stream. Let flask come to room temperature, stopper and weigh.

\section{Procedure}

Fill a dry 100-ml. pycnometer with sample and adjust to temperature specified. Transfer contents to the distillation flask. Rinse pycnometer three times, using a total of $50 \mathrm{ml}$. cold water, adding the rinsing to the flask. If foaming is expected, add a small amount of tannin. Complete distillation connections and distill into pycnometer flask until a volume of about $95-98 \mathrm{ml}$. has been collected. Remove pycnometer and place in water bath at constant temperature specified on pycnometer. After 15 minutes dilute exactly to the mark, using water at the same temperature. Dry inside neck and outside of pycnometer and then weigh.

\section{Calculations}

sp.gr. of distillate $=\frac{w t . \text { pycnometer with distillate }- \text { wt. empty pycnometer }}{\text { wt. pycnometer with water }- \text { wt. empty pycnometer }}$

From an alcohol table for $60^{\circ} \mathrm{F}$. find the corresponding alcohol content (\% by volume). 


\section{ALCOHOL}

(By Distillation and Hydrometer)

\section{Principle}

A measured volume of sample is distilled and the distillate diluted to a definite volume, usually the original volume. The alcohol content of the distillate is determined by means of a hydrometer.

\section{Procedure}

Pipette 100-ml. sample into the distillation flask and add $50 \mathrm{ml}$. water. Add a small amount of tannin if foaming occurs. (Note: A small amount of added Antifoam "A" (Dow Corning) prevents foaming.) If an abnormal quantity of acetic acid is present, neutralize exactly with $1 \mathrm{~N} \mathrm{NaOH}$. Place a 250-ml. Erlenmeyer flask in position to collect the distillate. With low heat distill about 90 to $95 \mathrm{ml}$. into the flask. Remove the flask, transfer distillate to a 200-ml. volumetric flask, cool to required temperature and make up to volume with water.

Note the temperature on the stem of the hydrometer. Cool the distillate to exactly this temperature in an ice bath. Fill the hydrometer cylinder with distillate, check temperature and insert hydrometer. Read the percent alcohol at the bottom of the meniscus, that is, at the general level of the liquid. Multiply the result by the dilution factor to obtain the percentage of al cohol.

A specific gravity hydrometer may be used instead of one reading in percent alcohol. Tables are available to convert specific gravity of alcohol water mixtures to percent alcohol by volume.

\section{TOTAL ACIDITY}

\section{Principle}

Total acidity is determined by direct titration with $0.1 \mathrm{~N} \mathrm{NaOH}$ to $\mathrm{pH}$ 8.1, using a pH meter.

\section{Procedure}

Weigh 10-gm. sample into a 250-ml. beaker. Add $100 \mathrm{ml}$. water and bring quickly to boil to expel $\mathrm{CO}_{2}$. Do not continue boiling because volatile acids may be lost. Cool the sample and titrate to $\mathrm{pH} 8.1$ with $0.1 \mathrm{~N} \mathrm{NaOH}$, using a $\mathrm{pH}$ meter. Record volume of $\mathrm{NaOH}$ required and calculate the total acidity as percent of the predominant acid.

\section{Calculations}

$1 \mathrm{ml} .0 .1 \mathrm{~N} \mathrm{NaOH}=0.0075 \mathrm{gm}$. tartaric acid 
If $5.8 \mathrm{ml} .0 .1 \mathrm{~N} \mathrm{NaOH}$ were required for titration:

$\%$ total acid $=\frac{1}{10} \times \frac{\text { equiv. wt. of acid } \times \text { normality of } \mathrm{NaOH} \times \text { titer }}{\text { wt. of sample }}$

$$
=\frac{1}{10} \times \frac{75.0 \times 0.1 \times 5.8}{10}
$$

Note: See page 3 for equivalent weights of acids.

\section{TANNIN AND COLORING MATTER}

\section{Principle}

A de-alcoholized sample is titrated with standard potassium permanganate using indigo solution as an indicator. The volume of permanganate solution required minus that required to oxidize a similar aliquot from which the tannin and coloring matter were removed is the volume of permanganate required to oxidize the tannin.

\section{Reagents}

1. Potassium permanganate $-0.1 \mathrm{~N}$

Dissolve $3.160 \mathrm{gm}$. in about $200 \mathrm{ml}$. water. Transfer to $1,000-\mathrm{ml}$. volumetric flask and make up to volume with water at $20^{\circ}$. Standardize with sodium oxalate as on page 46 .

2. Indigo solution

Dissolve $3 \mathrm{gm}$. sodium indigotin disulfonate in $200 \mathrm{ml}$. water by heating, cool, add slowly $25 \mathrm{ml}$. conc. $\mathrm{H}_{2} \mathrm{SO}_{4}$. Transfer to $500-\mathrm{ml}$. volumetric flask and dilute to mark with water.

3. Purified boneblack

Boil $200 \mathrm{gm}$. powdered boneblack with two successive portions of $\mathrm{HCl}(1+3)$. Filter through hard filter paper, wash with boiling water until chloride-free (test with $\mathrm{AgNO}_{3}$ ). Place in flask and keep covered with water. If acid-washed charcoal is available, this step c an be eliminated.

\section{Procedure}

Pipette $100 \mathrm{ml}$. wine or cider into $400-\mathrm{ml}$. beaker. Add about $25 \mathrm{ml}$. water and remove alcohol by evaporating on a hot plate to about $75 \mathrm{ml}$. Cool, transfer to $100-\mathrm{ml}$. volumetric flask, rinsing the beaker several times. Cool and make up to volume.

Pipette $10 \mathrm{ml}$. of the de-alcoholized sample into a 2,000-ml. porcelain evaporating dish. Add $1,000 \mathrm{ml}$. water and exactly $20 \mathrm{ml}$. indigo solution (reagent 2). Add the standard $\mathrm{KMnO}_{4}$ solution from a burette $1 \mathrm{ml}$. at a time until the blue color changes to green, then add a few drops at a time until the color becomes golden yellow. Designate number of $\mathrm{ml}$. of $\mathrm{KMnO}_{4}$ solution as "a." 
Transfer remaining de-alcoholized sample from the volumetric flask to a 250-ml. Erlenmeyer flask. Add about $1 \mathrm{gm}$. prepared boneblack and after 10 minutes, with occasional shaking, filter through No. $41 \mathrm{H}$ or No. 5 paper. The carbon adsorbs tannin, other nontannins and anthocyanins. The filtrate must be crystal clear.

Pipette $10 \mathrm{ml}$. of decolorized sample into a 2,000-ml. porcelain evaporating dish. Add $1,000 \mathrm{ml}$. water and exactly $20 \mathrm{ml}$. indigo solution. Titrate with the $\mathrm{KMnO}_{4}$ solution as directed above. Designate $\mathrm{ml} . \mathrm{KMnO}_{4}$ as "b."

\section{Calculations}

$1 \mathrm{ml} .0 .1 \mathrm{NMnO}_{4}=0.00416 \mathrm{gm}$. tannin and coloring matter.

$\%$ tannin and coloring matter $=\frac{(\mathrm{a}-\mathrm{b}) \times \text { normality of } \mathrm{KMnQ}_{4}}{\text { wt. of sample titrated }} \times 4.16$

\section{References}

Cruess, W. V., M. A. Joslyn and L. G. Saywell. Laboratory examination of wines and other fermented products, pp. 66-69. Avi Publishing Co. Inc., New York, N.Y. 1934.

\section{TOTAL AND REDUCING SUGARS}

(Total Sugar - Dry Wines and Cider)

\section{Reagents}

See "Jams, Jellies and Marmalades."

\section{Preparing the Sample}

Weigh 200-gm. sample into $400-\mathrm{ml}$. beaker, neutralize with $1 \mathrm{~N} \mathrm{NaOH}$ to $\mathrm{pH} 8.1$ on meter and evaporate to about $100 \mathrm{ml}$. Cool, transfer to $200-\mathrm{ml}$. volumetric flask and make up to volume at $20^{\circ}$. Transfer to $400-\mathrm{ml}$. beaker, add about $1 \mathrm{gm}$. decolorizing charcoal, shake, and let stand for 10 minutes. If necessary add one teaspoon of Hyflo Super-cel or similar filter aid, shake and filter through $41 \mathrm{H}$ paper. The filtrate must be clear and if so may be used directly in the "Standard Method" titration as under "Jams, Jellies and Marmalades." This applies where it can be safely assumed that the sugar present is all reducing sugar.

\section{Calculations}

$$
\% \text { sugar }=\frac{\text { factor }}{\text { titer }}(\text { from Table } 3) \times \frac{100}{1000}
$$




\section{(Total and Reducing Sugar - Sweet Nines and Cider)}

Preparing the Sample

Weigh 25-gm. sample into 400-ml. beaker. Add about $150 \mathrm{ml}$. water and neutralize to $\mathrm{pH} 7.5-8.0$ with $1 \mathrm{~N} \mathrm{NaOH}$. Evaporate to about $100 \mathrm{ml}$. (20-25 minutes' boiling). Cool, transfer to 250-ml. volumetric flask, add 100-200 ml. water and $2 \mathrm{ml}$. lead acetate solution. Shake, and let stand for 10 minutes. Add the necessary amount of potassium oxalate (see "Jams, Jellies and Marmalades"), bring up to volume with water and filter through $41 \mathrm{H}$ or No. 5 paper. Test filtrate with small amount of potassium oxalate to determine if lead is absent. If filtrate is clear, follow the procedure for "Total and Reducing Sugars," under "Fruit Juices," using 50-ml. aliquots.

\section{Calculations}

See "Total and Reducing Sugars," under "Fruit Juices."

\section{References}

Cruess, W.V., M.A. Joslyn and L. G. Saywell. Laboratory examination of wines and other fermented products. pp. 52-58. Avi Publishing Co. Inc., New York, N.Y. 1934.

\section{IRON}

\section{Wet Ashing}

(Colorimetric Method)

\section{Reagents}

1. Nitric acid - concentrated

2. Perchloric acid $-72 \% \mathrm{HClO}_{4}$

\section{Procedure}

Pipette $25 \mathrm{ml}$. of thoroughly degassed sample into 125-ml. Erlenmeyer flask and boil down to a thick syrup, slightly charred. Add 20-25 ml. $\mathrm{HNO}_{3}$ and $2 \mathrm{ml} . \mathrm{HClO}_{4}$ to flask and heat gently in fume cabinet until initial reaction begins. This is indicated by vigorous boiling with evolution of brown nitrogen tetroxide.

After reaction has subsided, again heat contents of the flask to slow boiling and continue boiling until all $\mathrm{HNO}_{3}$ is driven off as evidenced by evolution of fumes of $\mathrm{HClO}_{4}$. When cooled, the residue should be colorless or at the most a pale yellow. If not, add small amounts of $\mathrm{HNO}_{3}$ and $\mathrm{HClO}_{4}$ and heat further. After contents are completely ashed and cooled, transfer to $100-\mathrm{ml}$. volumetric flask and make up to volume.

\section{Preparation of Standard Curve}

\section{Reagents}

1. Glass-distilled water 
2. Acetic acid-2M

Dilute $120 \mathrm{gm}$. acetic acid to 1 liter with water.

3. Ammonium citrate solution- $1 \%$

Dissolve $1 \mathrm{gm}$. ammonium citrate in water and dilute to $100 \mathrm{ml}$.

4. Bromophenol blue indicator $-0.04 \%$

Dissolve $0.1 \mathrm{gm}$. bromophenol blue in $3 \mathrm{ml} .0 .05 \mathrm{~N} \mathrm{NaOH}$, transfer to a volumetric flask and dilute to $250 \mathrm{ml}$. with water.

5. Buffer solutions

(a) $\mathrm{pH} 3.5-$ Mix $6.4 \mathrm{ml} .2 \mathrm{M}$ sodium acetate with $93.6 \mathrm{ml} .2 \mathrm{M}$ acetic acid and dilute to 1 liter.

(b) $\mathrm{pH} 4.5$ - Mix $43 \mathrm{ml}$. $2 \mathrm{M}$ sodium acetate with $57 \mathrm{ml} .2 \mathrm{M}$ acetic acid and dilute to 1 liter.

6. Hydroquinone solution-1\%

Dissolve $1 \mathrm{gm}$. hydroquinone in $100 \mathrm{ml}$.buffer solution ( $\mathrm{pH} 4.5$ ). Store in refrigerator and discard as soon as any color develops.

7. o-Phenanthroline solution

Dissolve $1 \mathrm{gm}$. o-phenanthroline monohydrate in water and dilute to $400 \mathrm{ml}$.

8. Sodium acetate solution-2M

Dissolve $272 \mathrm{gm} . \mathrm{NaC}_{2} \mathrm{H}_{3} \mathrm{O}_{2} \cdot 3 \mathrm{H}_{2} \mathrm{O}$ in water dilute to 1 liter.

9. Standard iron solution - No. $1-1 \mathrm{mg}$. Fe/ml.

Dissolve $1 \mathrm{gm}$. electrolytic iron in $50 \mathrm{ml} .10 \% \mathrm{H}_{2} \mathrm{SO}_{4}$. Cool and dilute to $l$ liter with water.

10. Standard iron solution-No. 2

Pipette $5 \mathrm{ml}$. of standard iron solution No. 1 into $500-\mathrm{ml}$. volumetric flask and make up to volume with water. One ml. of this solution contains $0.01 \mathrm{mg}$. Fe. (10 mcg.)

Pipette 2-, 4-, 6-, 8- and 10-ml. aliquots standard iron solution No. 2 into $25-\mathrm{ml}$. volumetric flasks and the same amounts into test tubes. Add 5 drops bromophenol blue indicator to aliquots in the test tubes and add sodium acetate solution until color matches that of equal volume of buffer solution of $\mathrm{pH} 3.5$ containing same quantity of indicator. Add $1 \mathrm{ml}$. of hydroquinone solution and $2 \mathrm{ml}$. o-phenanthroline solution to the aliquots in the volumetric flasks. Adjust $\mathrm{pH}$ of the contents to 3.5 by adding same volume of sodium acetate solution as found necessary for aliquot in test tubes. Prepare a blank according to above procedure but omitting standard iron solution No. 2. Make all $25-\mathrm{ml}$. volumetric flasks up to volume with water, mix thoroughly and plot optical density against concentration on graph paper at wave length of $510 \mathrm{~m} \mu$.

\section{Procedure}

Pipette $10 \mathrm{ml}$. of digested sample into $25-\mathrm{ml}$. volumetric flask and same amount into a test tube. Add 5 drops bromophenol indicator to aliquot in 
test tube and titrate with sodium acetate solution until color matches that of equal volume of buffer solution of $\mathrm{pH} 3.5$ containing the same quantity of indicator.

Add $1 \mathrm{ml}$. hydroquinone solution and $2 \mathrm{ml}$. o-phenanthroline solution to aliquot in volumetric flask. Adjust $\mathrm{pH}$ of contents to 3.5 by adding same volume of sodium acetate solution as was found necessary for aliquots in test tube. If turbidity develops upon adjustment of $\mathrm{pH}$ of aliquot in test tube, add $1 \mathrm{ml}$. $\mathrm{NH}_{4}$ citrate solution to volumetric flask before adding the sodium acetate solution.

Prepare blank according to the above procedure. Make all flasks up to volume with water andmix thoroughly. Let stand for 1 hour to assure complete color development. Take colorimeter readings and plot optical density on the same graph pape: as the standard curve.

\section{Calculations}

p.p.m. $\mathrm{Fe}=$ mcg. $\mathrm{Fe}$ from curve divided by 2.5 .

\section{References}

Association of Official Agricultural Chemists. Official methods of analysis. 8th ed. Washington, D.C. 1955.

\section{TOTAL VOLATILE ACIDITY}

\section{Principle}

Volatile acids are steam-distilled from the sample using a Hortvet type distillation apparatus, and titrated with standard sodium hydroxide. The acids are calculated as acetic acid.

\section{Procedure}

Boil about $200 \mathrm{ml}$. of water in the outer heating flask. Most flasks are provided with an outside vent tube. The water may be boiled in the outer flask with the vent tube open to remove the dissolved $\mathrm{CO}_{2}$, as well as to replace with steam the air in the flask surrounding the inner tube. Apply heat gently and turn on cold water through condenser.

With a pipette, introduce a $20-\mathrm{ml}$. sample into inner tube and connect at once to the condenser. Increase the heat and bring the water in flask to vigorous boiling, having the pinch cock on side of the tube open. When the water is boiling vigorously, close the pinch cock. Steam passes through the 20 -ml. sample, carrying the volatile acid into the condenser. Collect the condensate in a 250-ml. Erlenmeyer flask. Continue distillation until 100 ml. is collected.

Transfer the $100 \mathrm{ml}$. of distillate to $250-\mathrm{ml}$. beaker. Add about 50 to $100 \mathrm{ml}$. of water and titrate with $0.1 \mathrm{~N} \mathrm{NaOH}$ to $\mathrm{pH} 8.1$. 


\section{Calculations}

$1 \mathrm{ml} .0 .1 \mathrm{~N} \mathrm{NaOH}=0.006$ gm. acetic acid

\section{Note:}

To determine whether all the volatile acids have been extracted, $50 \mathrm{ml}$. of distillate is first collected in one flask and titrated. An additional 10-ml. portion is then collected in a second flask and added to the distillate in the first flask and titrated. Further 10-ml. portions are distilled over until an additional $10-\mathrm{ml}$. portion does not change the titration by more than one or two drops. Generally only $80 \mathrm{ml}$. of distillate is required.

\section{References}

Cruess, W.V., M. A. Joslyn and L. G. Saywell. Laboratory examination of wines and other fermented products. pp. 33-44. Avi Publishing Co. Inc., New York, N.Y. 1934.

\section{VOLATILE ACIDITY}

(Exclusive of $\mathrm{SO}_{2}$ )

\section{Principle}

After removal of the free sulfur dioxide by addition of barium hydroxide, the volatile acids are steam-distilled from the sample and titrated with standard sodium hydroxide.

\section{Procedure}

Pipette 50-ml. sample into $250-\mathrm{ml}$. beaker, and add enough clear saturated $\mathrm{Ba}(\mathrm{OH})_{2}$ solution to bring mixture to $\mathrm{pH} 8.1$. Allow to stand 30 minutes and maintain at $\mathrm{pH} 8.1$ by adding more $\mathrm{Ba}(\mathrm{OH})_{2}$ if necessary. Transfer to $100-\mathrm{ml}$. volumetric flask, dilute to volume and filter immediately through No. 2 Whatman paper. Pipette $20 \mathrm{ml}$. of filtrate into inner tube of volatile acidity distillation flask and add $1 \mathrm{ml}$. of $\mathrm{H}_{2} \mathrm{SO}_{4}(\mathrm{l}+3)$. Place $150 \mathrm{ml}$. recently boiled hot water in outer flask and distill $100 \mathrm{ml}$. Using $\mathrm{pH}$ meter, titrate with $0.1 \mathrm{~N} \mathrm{NaOH}$ to $\mathrm{pH} 8.1$.

$1 \mathrm{ml} .0 .1 \mathrm{~N} \mathrm{NaOH}=0.006$ gm. acetic acid

\section{References}

Association of Official Agricultural Chemists. Official methods of analysis. 8th ed. p. 189. Washington, D.C. 1955.

\section{EXTRACT}

The "extract" of wine and cider represents the alcohol-free soluble solids present and consists mainly of tartaric acid, potassium bitartrate, malic acid, protein, coloring matter, sugar and gums. 
One method of determining the extract is to de-alcoholize the sample by boiling, dilute to the original volume and determine specific gravity with a Brix or Balling hydrometer. The other method is to evaporate a measured volume of sample to dryness and weigh the extract.

\section{(Hydrometer Method)}

\section{Procedure}

Pipette $100-\mathrm{ml}$. sample into $400-\mathrm{ml}$. beaker. Add $50 \mathrm{ml}$. water and evaporate slowly to a volume of about $50 \mathrm{ml}$. Avoid loss by spattering. Transfer to $100-\mathrm{ml}$. volumetric flask and rinse the beaker with water. Add the washings to the flask. Cool and dilute to mark. Transfer to a cylinder and insert a Brix or Balling hydrometer. The reading gives the grams of extract per $100 \mathrm{ml}$. of original sample. (For approximate purposes the refractometer reading gives a satisfactory result.)

\section{(Oven Method)}

\section{Procedure}

Place empty evaporating dishes in oven at $100^{\circ}$ for 1 hour. Transfer to desiccator, cool and weigh. Pipette 50-ml. sample into evaporating dish and heat on water bath until the liquid has evaporated to a viscous consistency. Place dishes in vacuum oven at $70^{\circ}$ and 26 to 28 inches vacuum for 8 hours. Place in desiccator, cool and weigh.

\section{Calculations}

$$
\% \text { extract }=\frac{w t . \text { of extract } \times 100}{\text { wt. of sample }}
$$




\title{
SAUERKRAUT
}

\section{TOTAL ACIDITY}

\section{Procedure}

From the liquid portion of the product weigh $5 \mathrm{gm}$. into $250-\mathrm{ml}$. beaker. Add $100 \mathrm{ml}$. water, boil for a few minutes to drive off $\mathrm{CO}_{2}$, cool and titrate with $\mathrm{pH}$ meter to $\mathrm{pH} 8.1$, using $0.1 \mathrm{~N} \mathrm{NaOH}$.

\section{Calculations}

$\%$ lactic acid $=\frac{\text { titer } \times \mathrm{N} \times \text { equiv. wt. } \times 100}{1,000 \times \text { wt. of sample }}$

If $7.2 \mathrm{ml} .0 .1 \mathrm{~N} \mathrm{NaOH}$ were required for titration:

$\%$ lactic acid $=\frac{7.2 \times 0.1 \times 90.08 \times 100}{1,000 \times 5}$

$$
=1.3
$$

$\mathrm{pH}$

\section{Procedure}

Adjust $\mathrm{pH}$ meter with $\mathrm{pH} 4.0$ buffer solution.

Pour 50 to $75 \mathrm{ml}$. of juice into $100-\mathrm{ml}$. beaker and take $\mathrm{pH}$ reading.

\section{FRUIT PRESERVED IN SULFUR DIOXIDE}

\section{SULFUR DIOXIDE}

\author{
(Official Method)
}

\section{Preparing the Material}

Place portion of material for analysis free from pits into Waring blendor jar. Blend just long enough to mix into a slurry. Place portion into an airtight container until ready for analysis.

\section{Procedure}

Using $25 \mathrm{gm}$. blended sample, follow the procedure for "Jams, Jellies and Marmalades."

\section{(Control Method)}

\section{Principle}

The sulfur dioxide solution is titrated directly against $0.05 \mathrm{~N}$ iodine solution using starch as indicator. This control method is useful for determining the amount of sulfur dioxide in stock solutions or for estimating the sulfur dioxide content of fruit pulp preserved in this manner. 


\section{Reagents}

1. Iodine solution $-0.05 \mathrm{~N}$

Dissolve $6.346 \mathrm{gm}$. iodine in a solution of $12 \mathrm{gm}$. potassium iodide in $100 \mathrm{ml}$. water and dilute to 1 liter.

2. Starch solution

Mix $0.5 \mathrm{gm}$. soluble starch with a little cold water (about 15 $\mathrm{ml}$.), pour into $100 \mathrm{ml}$. hot water and boil 1 to 2 minutes. Add enough $\mathrm{NaCl}$ to saturate, and store in a refrigerator, where it keeps for several weeks.

\section{Procedure}

With a $100-\mathrm{ml}$. pipette (inverted), remove about $100 \mathrm{ml}$. solution through the bunghole of the barrel. If the solution is not clear, filter through No. 4 Whatman paper into a 400-ml. beaker. Transfer the filtered solution to a 50 -ml. burette as quickly as possible.

Pipette $10 \mathrm{ml} .0 .05 \mathrm{~N}$ iodine solution into a $500-\mathrm{ml}$. Erlenmeyer flask containing about $100 \mathrm{ml}$. water. Add $1 \mathrm{ml}$. starch solution. Titrate the $\mathrm{SO}_{2}$ solution from the burette into the flask containing the iodine solution, rotating the flask frequently to keep the solution well mixed. When the color of the iodine solution becomes purple, add the solution from the burette dropwise, stopping at the point where one drop causes all color to disappear from the iodine solution.

\section{Calculations}

$1 \mathrm{ml} .0 .05 \mathrm{~N}$ iodine reacts with $0.0016 \mathrm{gm} . \mathrm{SO}_{2}$

$$
\begin{aligned}
& \% \mathrm{SO}_{2}=\frac{\text { ml. iodine } \times \text { normality of iodine } \times 3.2}{\mathrm{ml} . \mathrm{SO}_{2} \text { solution required }} \\
& \text { p.p.m. } \mathrm{SO}_{2}=\% \mathrm{SO}_{2} \times 10,000
\end{aligned}
$$

\section{References}

Atkinson, F.E., and C.C. Strachan. Preservation of fruits with sulfur dioxide in British Columbia. Fruit Prod. J. 21: 5-8; 43-45; 60; 72-74; 110-112; 141-144; 153.1941.

Wiegand, E. H. Process for the manufacture of maraschino cherries. Western Canner and Packer 29: 33-34. 1937. 


\title{
MISCELLANEOUS PROCEDURES
}

\author{
CALCIUM
}

(Official Method)

\section{Principle}

Calcium is precipitated as calcium oxalate. The precipitate is dissolved in hot dilute sulfuric acid and titrated with standard potassium permanganate.

\section{Ashing}

Weigh duplicate 25-gm. blended samples into glazed procelain dishes. Evaporate to dryness on water bath or in forced-eir oven at $100^{\circ}$ and ash at low red heat (not to exceed 525') until free of carbon particles.

\section{Reagents}

1. Methyl orange $-0.05 \%$

Dissolve $0.05 \mathrm{gm}$. methyl orange in water and dilute to $100 \mathrm{ml}$.

2. Oxalic acid-2.5\%

Dissolve $12.5 \mathrm{gm}$. oxalic acid in water and dilute to $500 \mathrm{ml}$.

3. Sodium acetate-20\%

Dissolve $100 \mathrm{gm}$. sodium acetate in water and dilute to $500 \mathrm{ml}$.

4. Saturated ammonium oxalate solution. To $12.0 \mathrm{gm}$. $\left(\mathrm{NH}_{4}\right)_{2} \mathrm{C}_{2} \mathrm{O}_{4} \cdot \mathrm{H}_{2} \mathrm{O}$ add $200 \mathrm{ml}$. of water.

\section{Procedure}

Dissolve the ash obtained above in $50 \mathrm{ml}$. of $\mathrm{HCl}(1+4)$ and heat for a few minutes. Be sure residue is acid. Filter through $15-\mathrm{cm}$. diameter No. 2 Whatman paper and wash thoroughly. Collect the washings in a $200-\mathrm{ml}$. volumetric flask. Make up to volume at $20^{\circ}$. To this filtrate or an aliquot, add 2 drops of methyl orange, and then ammonium hydroxide $(1+4)$ drop by drop, until the solution is just alkali. Add dilute HCl $(1+4)$ drop by drop until the solution is just acid. (When solution is cold and acid to the indicator, all the calcium phosphate is in solution. A small amount of phosphate or iron may remain undissolved at this point, but goes into solution when $0.5 \mathrm{~N}$ acid is added.)

When the solution is just acid, add $10 \mathrm{ml}$. of $0.5 \mathrm{~N} \mathrm{HCl}$ and $10 \mathrm{ml}$. $2.5 \%$ oxalic acid. Heat the solution to the boiling point. Add $10 \mathrm{ml}$. of $20 \%$ solution of sodium acetate with constant stirring. Boil gently for 10 minutes. Add a few drops of saturated ammonium oxalate solution to make sure that all the calcium is precipitated. Hold overnight at 32 to $40^{\circ} \mathrm{F}$.

Filter through $11-\mathrm{cm}$. diameter No. 40 Whatman paper into a beaker. Wash the precipitate free of chlorides with cold water (test with $\mathrm{AgNO}_{3}$ ). Wash the precipitate into a $400-\mathrm{ml}$. beaker using hot water from wash bottle. 
Keep the filter paper to add later in the titration. Make up to about 200 ml. with water, add $5 \mathrm{ml}$. conc. $\mathrm{H}_{2} \mathrm{SO}_{4}$ and heat to 70 to $80^{\circ} \mathrm{C}$. Titrate hot with $0.1 \mathrm{~N} \mathrm{KMnO}_{4}$ almost to completion (slight pink color). Add the filter paper in strips and complete titration to the first permanent pink color.

\title{
Calculations
}

$1 \mathrm{ml} .0 .1 \mathrm{~N} \mathrm{KMnO}_{4}=0.002$ gm. calcium

\section{References}

Association of Official Agricultural Chemists. Official methods of analysis.

8th ed. p. 378. Washington, D.C. 1955.

Snell, D. F., and C.T. Snell. Colorimetric methods of analysis. Vol. II. 3rd ed. D. Van Nostrand Co., New York. 1949.

\section{TANNIN AND COLORING MATTER}

\author{
(Fruits and Fruit Products)
}

\section{Principle}

In a neutral solution, tannin and coloring matter react with permanganate and are measured by titration, using indigo solution as an indicator. As these solutions contain other oxidizable matter besides tannin, it is necessary to separate these using charcoal and titrating a second time to determine the quantity of permanganate actually required by the tannin present.

\section{Reagents}

See "Tannin and Coloring Matter," under "Wines and Cider."

\section{Procedure}

For light-colored products such as peach, apple and pear. use a blended 50-gm. sample; for deeper-colored products, use $25 \mathrm{gm}$.

Transfer the sample to $600-\mathrm{ml}$. beaker, add $300 \mathrm{ml}$. of water and boil gently for 1 hour, replacing the water lost by evaporation.Cool, transfer to $500-\mathrm{ml}$. volumetric flask and dilute to mark. Mix thoroughly and filter through No. 4 Whatman paper.

Pipette $400 \mathrm{ml}$. of filtrate into $600-\mathrm{ml}$. beaker, add $0.3 \mathrm{gm}$. powdered $\mathrm{CaCO}_{3}$ and heat to boiling. Cool, transfer to $500-\mathrm{ml}$. volumetric flask and make up to volume. Mix thoroughly, and filter through No. 5 Whatman paper, refiltering if necessary until brilliantly clear.

Pipette $200 \mathrm{ml}$. filtrate into 2-liter procelain dish, add about $800 \mathrm{ml}$. of water and exactly $20 \mathrm{ml}$. of the indigo solution. Add standard $\mathrm{KMnO}_{4}$ solution $1 \mathrm{ml}$. at a time, stirring vigorously until the blue color changes to green, then add a few drops at a time until the color becomes a golden yellow. Designate the ml. of $\mathrm{KMnO}_{4}$ used as "a." 
To the remaining filtrate add $1 \mathrm{gm}$. carbon and shake intermittently for 10 minutes. Filter through No. 5 Whatman paper, refiltering if necessary until clear. Pipette $200 \mathrm{ml}$. filtrate into the porcelain dish and add $800 \mathrm{ml}$. water and exactly $20 \mathrm{ml}$. of the indigo solution. Titrate with standard $\mathrm{KMnO}_{4}$ in the manner described above. Designate the ml. of $\mathrm{KMnO}_{4}$ solution required as "b."

\section{Calculations}

$1 \mathrm{ml} .0 .1 \mathrm{~N} \mathrm{KMnO}_{4}=0.0035$ gm. tannin $(\mathrm{a}-\mathrm{b})=\mathrm{ml} . \mathrm{KMnO}_{4}$ solution required for oxidation of tannin $\%$ tannin $=\frac{(\mathrm{a}-\mathrm{b}) \times \text { normality of } \mathrm{KMnO}_{4}}{\text { wt. of sample titrated }} \times 3.5$

\section{References}

Hartman, B. E. The polybasic acids of fruits and fruit products. Tannin and coloring matter. J. Assoc. Offic. Agr. Chemists 26: 452-462. 1943. Strachan, C.C., A. W. Moyls, F.E. Atkinson and J. E. Britton. Chemical composition and nutritive value of British Columbia tree fruits. Canada Dept. Agr. Pub. 862. 1951.

\section{ENZYME TESTS FOR ADEQUACY OF BLANCHING IN FROZEN VEGETABLES}

\section{Principle}

This method is based upon measurement of the rate of color development in a guaiacol - hydrogen peroxide substrate under the catalytic influence of the enzyme present in the tissue. The reaction is brought about through the formation of an active peroxidase-peroxide complex, which oxidizes the colorless guaiacol directly to an orange-brown end product.

\section{Reagents}

1. Guaiacol solution-1\%

Dissolve $1 \mathrm{gm}$. or $0.9 \mathrm{ml}$. guaiacol in $50 \mathrm{ml}$. ethyl alcohol and add $50 \mathrm{ml}$. water.

2. Hydrogen peroxide- $1 \%$

Dilute 1 part $3 \% \mathrm{H}_{2} \mathrm{O}_{2}$ (free from preservatives) with 2 parts water.

Note: Glass dropping bottles of 100-ml. capacity are ideal containers. The reagents should be protected from light and stored in a refrigerator.

Testing reagents. The effectiveness of the reagents is determined by carrying out tests on two small pieces of fresh vegetables, one of which is boiled for 10 minutes and cooled. The fresh material should give a positive test, the heated one a negative test. 


\section{Preparing the Material}

Select representative material from portions that were heated least in the blanching, i.e., the central portions of the thickest pieces. Use a stainless steel cutting knife.

For spinach, chard or similar leafy material, select a number of leaves and take the inch midrib portion beginning at the base of the leafy portion.

For asparagus spears, cut off and discard $3 / 4$ inch from the butt end, then split the spears lengthwise.

For broccoli and cauliflower, split the stalk and head lengthwise.

For peas and other seed vegetables, cut each seed in half.

For string beans, cut $1 / 4-$ to $1 / 2$-inch cross sections from a number of beans and split these cross sections lengthwise.

\section{Procedure}

Place the prepared material on a white porcelain saucer or evaporating dish. Add enough guaiacol solution to wet all of the cut surfaces, then immediately add a similar amount of hydrogen peroxide solution. At the end of 3 minutes note whether a reddish-brown color has developed. If none is observed the test for peroxidase is negative. Neglect any color that may develop after 3 minutes. The reactions, as read at the end of 3 minutes, are graded as follows:

\section{References}

$$
\begin{array}{ll}
\text { negative } & \text { - no color } \\
\text { trace } & - \text { reddish-brown specks } \\
\text { faint } & - \text { up to } 25 \% \text { of the material colored } \\
\text { heavy } & - \text { material a solid reddish-brown color }
\end{array}
$$

Atkinson, F.E., C.C. Strachan and A. W. Moyls. B.C. Processor's Handbook. Fruit and Vegetable Processing Laboratory, Canada Dept. Agr. Experimental Farm, Summerland, B.C. Sept. 1947.

Joslyn, M. A. Report on peroxidase in frozen vegetables. J. Assoc. Offic. Agr. Chemists 36: 161-178. 1953.

\section{CRUDE FAT OR ETHER EXTRACT}

(For Fruit and Vegetable Products)

\section{Principle}

Fat-soluble material is extracted from an oven-dried sample using a Soxhlet extraction apparatus. The ether is evaporated and the remaining material weighed.

\section{Procedure}

Weigh 50 -gm. blended sample into a $250-\mathrm{ml}$. beaker. Add about $75 \mathrm{ml}$. water and about $5 \mathrm{gm}$. asbestos. Mix and filter through No. 4 Whatman 
filter paper. If globules of fat are present on the water layer, decant liquid into a separatory funnel and extract with several small portions of ether. If no fat is observed, liquid layer may be discarded. Keep the ether extract and combine it with sample before drying.

Place residue and filter paper in a thin aluminum foil dish and dry at $100^{\circ}$ until moisture is removed, usually overnight.

Remove from oven and when cool, cut the dish and contents into small pieces and transfer directly into Soxhlet extraction thimble. Extract in the Soxhlet apparatus with anhydrous ether for at least 16 hours.

Remove thimble from the apparatus and distill off most of the ether by allowing it to collect in the Soxhlet tube and pouring it off when the tube is nearly full. When the ether has reached a small volume, pour it into a small beaker through a small funnel containing a plug of cotton. Rinse the flask and filter thoroughly, using several small portions of ether.

Evaporate the ether on a steam bath at low heat, preferably under a current of air. Dry at $100^{\circ}$ for 1 hour, cool and weigh.

\section{Calculations}

$$
\% \text { crude fat }=\frac{\text { wt. of fat-soluble material } \times 100}{w t . \text { of sample }}
$$

\section{References}

National Canners Association. Laboratory manual for the canning industry. Section 20, p. 32. National Canners Association, Washington, D. C. 1954.

\section{ESTIMATION OF CALORIE CONTENT OF DIET FOODS}

\section{(Dietetic Fruit Spreads)}

Take refractometer reading of sample at $20^{\circ}$. Multiply the reading by 4 to estimate number of calories per $100 \mathrm{gm}$.

If soluble solids reading is $21 \%$ :

Calories per $100 \mathrm{gm} .=21.0 \times 4$

$$
=84 \text {. }
$$




\section{APPENDIX}

\section{STANDARD SOLUTIONS}

\section{ACIDS}

Hydrochloric Acid-0.1N (3.646 gm. per liter)

Use conc. $\mathrm{HCl}$ (strength usually stated on bottle).

$$
\frac{3.646 \times 100 \mathrm{gm} \text {. }}{37.3} \text { of } 37.3 \% \mathrm{HCl} \text { gives } 1 \text { liter of } 0.1 \mathrm{~N} \text { solution }
$$

Sp. gr. of conc. $\mathrm{HCl}=$ about 1.19

Therefore volume of conc. $\mathrm{HCl}$ required:

$$
\frac{3.646 \times 100}{37.3 \times 1.19}=8.2 \mathrm{ml} \text {. per liter for } 0.1 \mathrm{~N} \text { solution }
$$

Standardize against:

Standard 0.1N NaOH (titrate to $\mathrm{pH} 8.1$ )

Succinic Acid-0.1 $\mathrm{N} \mathrm{H}_{2} \mathrm{C}_{4} \mathrm{H}_{4} \mathrm{O}_{4}$ (5.9023 gm. per liter)

Dry 5 to $6 \mathrm{gm}$. pure succinic acid in open weighing bottle at $105^{\circ}$ for about 10 hours; cool and store in desiccator. Weigh 2.9511 gm., transfer to $400-\mathrm{ml}$. beaker and dissolve in 150 to $200 \mathrm{ml}$. of water. Pour the solution into $500-\mathrm{ml}$. volumetric flask, rinsing out the beaker several times to insure complete transfer of the acid. Dilute to exactly $500 \mathrm{ml}$. and mix thoroughly. This prepares an exact $0.1 \mathrm{~N}$ solution.

Sulfuric Acid-0.1N solution (4.904 gm. per liter)

Pour $3 \mathrm{ml}$. of conc. $\mathrm{H}_{2} \mathrm{SO}_{4}$ carefully into $10-12 \mathrm{ml}$. of water. Cool, mix thoroughly and dilute to 1 liter. Standardize by titration against standard $\mathrm{NaOH}$ or $\mathrm{KOH}$ to the phenolphthalein end point or to $\mathrm{pH} 8.1$ with a $\mathrm{pH}$ meter.

Oxalic Acid-normal (63.023 gm. $\mathrm{H}_{2} \mathrm{C}_{2} \mathrm{O}_{4} \cdot 2 \mathrm{H}_{2} \mathrm{O}$ per liter)

Decinormal or less concentrated solutions are unstable and should be prepared fresh when needed. More concentrated solutions may deposit some of the acid when cooled to low temperatures but they are fairly stable at room temperature when protected from light. 


\section{BASES}

Sodium Hydroxide-normal (40.005 gm. per liter)

Dissolve $42 \mathrm{gm}$. C.P. sodium hydroxide pellets in water and dilute to 1 liter in a volumetric flask.

Standardization of 'sodium hydroxide

1. For procedures using $\mathrm{pH} 8.1$ as the end point: against weighed portions of succinic acid.

Dry succinic acid crystals at $105^{\circ}$ for 8 hours and cool in desiccator. Take suitable portions of succinic acid (about $0.1 \mathrm{gm}$. for $0.1 \mathrm{~N} \mathrm{NaOH}$ and $0.05 \mathrm{gm}$. for $0.05 \mathrm{~N} \mathrm{NaOH}$ ) and weigh accurately on an analytical balance. Dissolve in about $150 \mathrm{ml}$. water in $250-\mathrm{ml}$. beakers. Titrate in duplicate with $\mathrm{NaOH}$ solution to $\mathrm{pH} 8.1$.

\section{Calculations}

N ormality of $\mathrm{NaOH}=\frac{\mathrm{wt} \text {. of succinic acid } \times 1,000}{\mathrm{ml} . \mathrm{NaOH} \times \text { equiv. wt. of acid }}$

If $0.1047 \mathrm{gm}$. succinic acid required $17.1 \mathrm{ml} . \mathrm{NaOH}$ :

Normality of $\mathrm{NaOH}=\frac{0.1047 \times 1,000}{17.1 \times 59.03}$

2. For procedures using bromophenol blue as indicator; against standard $\mathrm{H}_{2} \mathrm{SO}_{4}$.

Stan dardization of $\mathrm{H}_{2} \mathrm{SO}_{4}$ against $\mathrm{Na}_{2} \mathrm{CO}_{3}$

Heat $\mathrm{Na}_{2} \mathrm{CO}_{3}$ at $105^{\circ}$ for 8 hours. Weigh out exactly 1.3250 gm., dissolve and make up to $250 \mathrm{ml}$. This makes exactly $0.1 \mathrm{~N} \mathrm{Na}_{2} \mathrm{CO}_{3}$ solution.

Pipette $5 \mathrm{ml} . \mathrm{H}_{2} \mathrm{SO}_{4}$ into 125 -ml. Erlenmeyer flask. Add about $25 \mathrm{ml}$. water and 4 drops bromophenol blue. Titrate $\mathrm{Na}_{2} \mathrm{CO}_{3}$ from burette to a blue end point or $\mathrm{pH} 4.1$, using a $\mathrm{pH}$ meter.

Standardization of $\mathrm{NaOH}$ against $\mathrm{H}_{2} \mathrm{SO}_{4}$

Pipette $5 \mathrm{ml}$. standardized $0.1 \mathrm{~N} \mathrm{H}_{2} \mathrm{SO}_{4}$ into $125-\mathrm{ml}$. Erlenmeyer flask. Add about $25 \mathrm{ml}$. water and 4 drops bromophenol blue indicator. Titrate $\mathrm{NaOH}$ from burette to color end point, or $\mathrm{pH} 4.1$ using a $\mathrm{pH}$ meter.

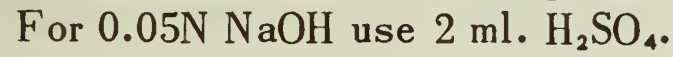

\section{OXIDIZING AND REDUCING SOLUTIONS}

Potossium Dichromate-0.1N (4.9037 gm. per liter)

Dry crystals at 120 to $140^{\circ}$ for 2 to 4 hours. Cool in a desiccator and weigh $5.0 \mathrm{gm}$. to the nearest milligram. Dissolve in about $200 \mathrm{ml}$. water and transfer to 1-liter volumetric flask, dilute to volume and mix thoroughly:

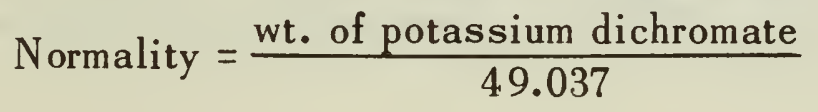


Potassium Permanganate-0.1N (3.1606 gm. per liter)

Dissolve $3.3 \mathrm{gm}$. of dry $\mathrm{KMnO}_{4}$ in about $200 \mathrm{ml}$. water and transfer to a 1-liter flask. Make up to volume at $20^{\circ}$.

\section{Standardization with sodium oxalate}

Weigh out accurately three 0.25 - to 0.30 -gm. samples of sodium oxalate having an assay value of $99.95 \%$, transfer each portion to a $600-\mathrm{ml}$. beaker, using $250 \mathrm{ml}$. dilute sulfuric acid $(5+95)$. Stir until the oxalate has dissolved, then add rapidly from a burette about $95 \%$ of the amount of permanganate needed for complete oxidation of the sample. Allow the solution to stand until the permanganate is decolorized, then heat to 55 to $60^{\circ}$. Complete the titration at this temperature, stirring gently and allowing each drop to become decolorized before adding the next; titrate to first permanent pink.

$$
\text { Normality of } \mathrm{KMnO}_{4}=\frac{\text { gm. sodium oxalate } \times 1,000}{\mathrm{ml} \text {. of } \mathrm{KMnO}_{4} \times 67.0}
$$

\section{Sodium Thiosulfate-0.1N (24.8192 gm. $\mathrm{Na}_{2} \mathrm{~S}_{2} \mathrm{O}_{3} \cdot 5 \mathrm{H}_{2} \mathrm{O}$ per liter)}

Weigh $25.0 \mathrm{gm}$., dissolve in $200 \mathrm{ml}$. water, transfer to 1-liter flask and make up to volume. Mix the solution thoroughly, allow it to stand for a few days, and then siphon off the clear liquid. The solution is standardized indirectly with potassium dichromate.

\section{Standardization with potassium dichromate}

Accurately weigh 0.20 - to 0.23 -gm. $\mathrm{K}_{2} \mathrm{Cr}_{2} \mathrm{O}_{7}$ (dried 2 hours at $105^{\circ}$ ). Transfer to $250-\mathrm{ml}$. beaker using about $150 \mathrm{ml}$. water. Add $2 \mathrm{gm}$. potassium iodide and mix. Add $20 \mathrm{ml}$. $1 \mathrm{~N} \mathrm{HCl}$, swirl, and let stand for 10 minutes. Start titrating with the sodium thiosulfate from burette, adding about $80 \%$ of the required amount. Add $1 \mathrm{ml}$. starch and complete titration to point where solution changes from blue-green to light green.

$$
\text { Normality }=\frac{\mathrm{gm} . \mathrm{K}_{2} \mathrm{Cr}_{2} \mathrm{O}_{7} \times 1000}{\mathrm{ml} \cdot \mathrm{Na}_{2} \mathrm{~S}_{2} \mathrm{O}_{3} \times 49.037}
$$

lodine-0.1N (12.693 gm. per liter)

Dissolve $13.5 \mathrm{gm}$. pure resublimed iodine in a solution of $24 \mathrm{gm}$. potassium iodide in $200 \mathrm{ml}$. of $\mathrm{H}_{2} \mathrm{O}$ and dilute to 1 liter. The solution is standardized by titrating against a known volume of standard thiosulfate, with a few drops of starch solution as indicator.

\section{INDICATORS}

Phenolphthalein $-\mathrm{pH}$ range 8.3 to 10

Dissolve $1 \mathrm{gm}$. in $100 \mathrm{ml}$. neutral ethyl alcohol and water. Use 1 drop per $100 \mathrm{ml}$. solution. 
Methyl red-pH range 4.4 to 6.0

Dissolve $1 \mathrm{gm}$. in $100 \mathrm{ml} .95 \%$ ethyl alcohol. This indicator is easily reduced with loss of color, and readings must be made shortly after it is added to the solution.

Methyl orange $-\mathrm{pH}$ range 2.9 to 4.0

Dissolve $0.5 \mathrm{gm}$. in $1000 \mathrm{ml}$. water.

Bromophenol blue-pH range 3.0 to 4.6

Dissolve $0.1 \mathrm{gm}$. in $25 \mathrm{ml}$. water and dilute to $100 \mathrm{ml}$. with water.

Starch solution $-0.5 \%$

Dissolve $0.5 \mathrm{gm}$. soluble starch in about $15 \mathrm{ml}$. cold water and pour into $100 \mathrm{ml}$. hot water. Boil 1 to 2 minutes.

\section{Cleaning solution}

Sodium or potassium dichromate (commercial)

Water

$40 \mathrm{gm}$.

$150 \mathrm{ml}$.

Dissolve with a little heat if necessary, then cool to room temperature and add slowly $230 \mathrm{ml}$. conc. sulfuric acid (tech.).

Note: As a precaution this solution should always be prepared over a sink. 


DATE DUE

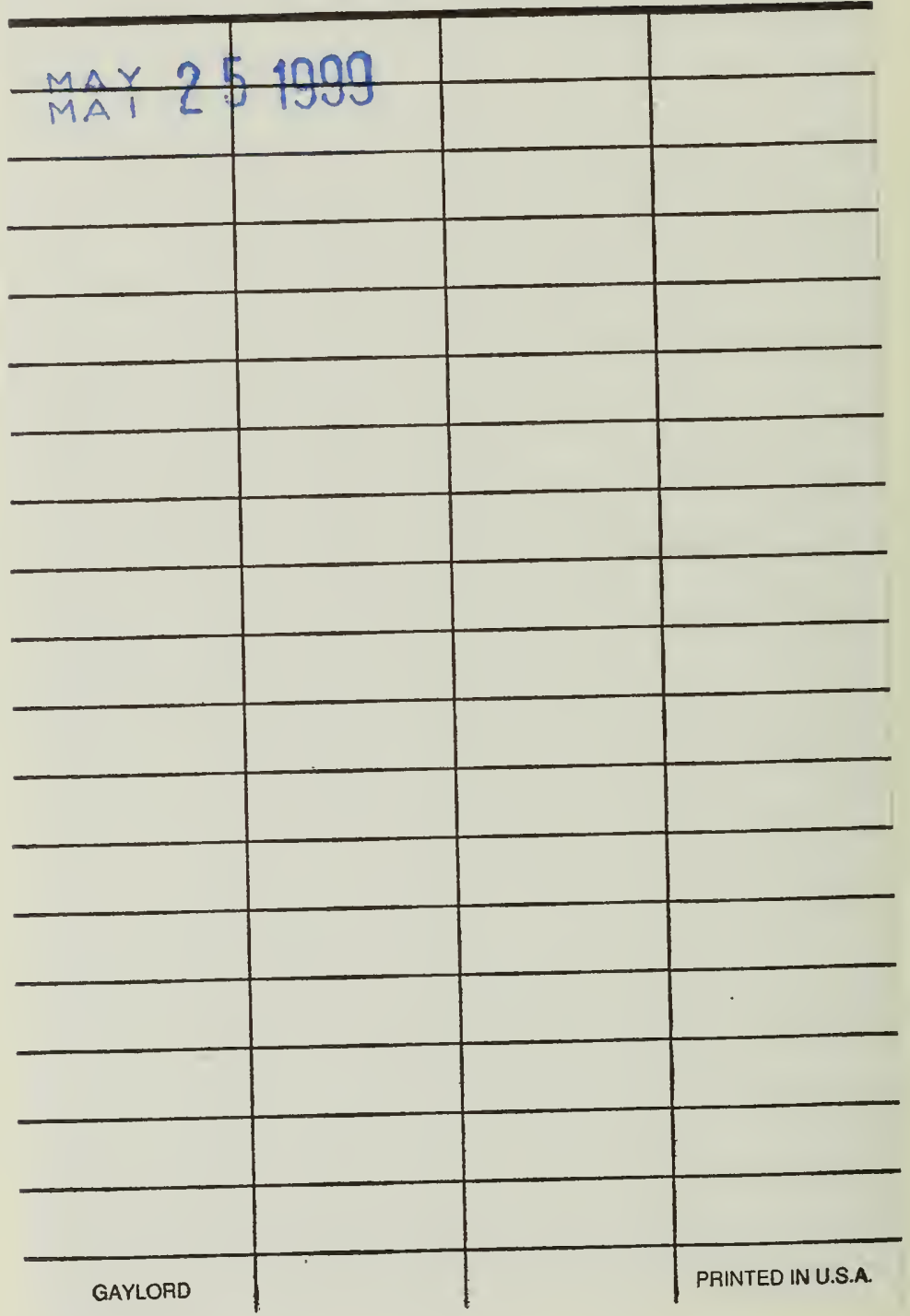




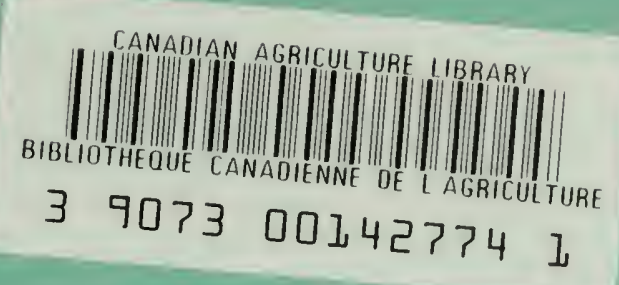


Copies of this publication may be obtained from:

INFORMATION DIVISION

CANADA DEPARTMENT OF AGRICULTURE

Ottawa 